Article

\title{
Two-Step Isolation, Purification, and Characterization of Lectin from Zihua Snap Bean (Phaseolus vulgaris) Seeds
}

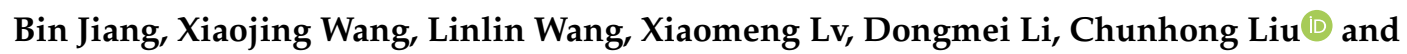 \\ Zhibiao Feng *
}

Department of Applied Chemistry, Northeast Agricultural University, NO.600 Changjiang Road Xiangfang District, Harbin 150030, China; jiangbin@neau.edu.cn (B.J.); neauwxj@163.com (X.W.); neauwll@163.com (L.W.); 18846173287@163.com (X.L.); lidongmei@neau.edu.cn (D.L.); liuchunhong@neau.edu.cn (C.L.)

* Correspondence: fengzhibiao@neau.edu.cn; Tel.: +86-4515-519-0222

Received: 9 April 2019; Accepted: 30 April 2019; Published: 2 May 2019

\begin{abstract}
A two-step method based on an aqueous two-phase system and Sephadex G-75 was used to separate and purify lectin from the seeds of the Zihua snap bean. The preliminary properties and bioactivity of the Zihua snap bean lectin were characterized by different instrumental methods, such as sodium dodecyl sulfate polyacrylamide gel electrophoresis (SDS-PAGE), liquid chromatography-nano electrospray ionization mass spectrometry (Nano LC-ESI-MS/MS), and Fourier transform infrared spectroscopy (FTIR). The hemagglutinating activity of the Zihua snap bean lectin could not be inhibited by glucose, $N$-acetyl-D-glucosamine, D-galactose, $N$-acetyl-D-galactosamine, fructose, sucrose, D-maltose, D-trehalose, and lactose. It was found that the hemagglutinating activity of the lectin showed strong dependence on $\mathrm{Mn}^{2+}$ and $\mathrm{Ca}^{2+}$. The thermal and $\mathrm{pH}$ stability of the Zihua snap bean lectin was studied by FTIR and fluorescence spectroscopy. Relatively good stability was observed when the temperature was not higher than $70{ }^{\circ} \mathrm{C}$, as well as in the $\mathrm{pH}$ range of 2.0 to 10.0. Digestive stability in vitro was investigated. The untreated lectin was relatively stable to pepsin and trypsin activity, but heat treatment could significantly reduce the digestive stability in vitro. Moreover, the lectin showed an inhibitory effect on the tested bacteria (Staphylococcus aureus (S. aureus), Escherichia coli (E. coli), Bacillus subtilis (B. subtilis)), and it also showed a certain inhibitory effect on the growth of Phytophthora infestans (P. infestans) at higher concentrations.
\end{abstract}

Keywords: Zihua snap bean; lectin; stability; preliminary property; bioactivity

\section{Introduction}

Lectins are glycoproteins that are characterized by their capability to attach carbohydrates such as mannose, galactose, lactose, $N$-acetyl glucosamine, $N$-acetyl galactosamie, fucose, and rhamnose with significant specificity [1]. They bind specifically and reversibly to different types of glycoproteins or carbohydrates [2,3]. Due to these advantages, some sensitive dielectric sensors based on Concanavalin A lectin were used for the specific identification of glycoproteins and carbohydrates $[4,5]$.

Exploratory studies on their health benefits have been initiated, because lectins have important physiological roles, including insecticidal action [3,6], antibacterial activity [7], and antifungal effects [8], antihuman immunodeficiency virus [9], antitumor activity [10-12], and analgesic activity [13]. Plants are the main source of lectins that are found in different parts of plants such as seeds, leaves, bark, roots, tubers, and fruits [14]. It has been known for a long time that lectins occur in legumes, where they can be a major food source for both humans and animals [15]. However, lectin has an antinutritional factor [16]. Its antinutritional properties are most likely caused by their impairment of the integrity 
of the intestinal epithelium, and thus also the absorption and utilization of the nutrients that are present in the legumes [17]. So, lectins containing foods are frequently consumed cooked or otherwise processed to reduce the level of the antinutritional factors and improve the utilization efficiency of legumes [18]. In addition, the lectins that are thought to survive gastric digestion have been a minor allergen, such as soybean seeds $[19,20]$. Therefore, its relevance to food safety requires intensive research to determine the digestibility of lectins from legumes, especially regarding the consumption of high levels of unprocessed or undercooked beans [21]. Thus, more and more legume lectins are being studied intensively. Lectin with a molecular mass of approximately $60 \mathrm{kDa}$ and two different subunits was isolated from the ground bean (Vigna sesquipedalis cv. ground bean) [22]. Lectin with a molecular mass of $67 \mathrm{kDa}$, and two identical subunits, was purified from Phaseolus vulgaris (P. vulgaris) cv. dark red kidney bean [23]. He et al. [24] extracted a lectin with the molecular weight of $49.24 \mathrm{kDa}$ from small black kidney bean (P. vulgaris) using a reversed micellar system.

The Zihua snap bean is a high quality bean that is distributed in northeast China. The protein content in Zihua snap bean seeds exceeds $20 \%$ [25], of which $2.4-5 \%$ is lectin [15]. In our previous studies, lectin was separated from the Zihua snap bean (P. vulgaris) seeds by an aqueous two-phase system (ATPS), which was effectively applied for the extraction and purification of proteins and other biomolecules [26-28].

In this study, seeds of the Zihua snap bean, which is an endemic species in northeast China, were chosen to separate and purify lectin by a two-step method based on an aqueous two-phase system and Sephadex G-75. On this basis, the partial properties of lectin were investigated. In addition, the in vitro digestion characteristics and antimicrobial activity of the lectin were also discussed. The purpose of the present work was to establish a two-step method for purifying lectin from the Zihua snap bean in local special crops and explore new sources of lectin. Furthermore, system information about the reduction of antinutritional factors of lectin by heat treatment and the effect of lectin preheating on digestion were provided. These laid the foundation for the deep processing of the Zihua snap bean to improve the economic value of the Zihua snap bean.

\section{Materials and Methods}

\subsection{Instruments}

An ultraviolet-visible spectrophotometer was from Beijing Purkinje General Instrument Co., Ltd. (Beijing China). An A150011 vortex mixer (Nanjing Jiajun Biological Co., Ltd., Nanjing, China) and a SC-3610 low speed centrifuge (Anhui Zhongke Zhongia Scientific Instrument Co., Ltd., Hefei, China) were applied to treat the sample. The Biorad Mini-PROTEAN Tetra Cells 4-Gel 165-8004 was from Bio-Rad Co., Ltd. (Guangzhou China). The $\mathrm{pH}$ of solution was measured by an FE201EL20 pH meter (Yidian Scientific Instrument Co., Ltd., Shanghai, China), and the weight of the sample was determined by an AL-04 electronic analytical balance (Mettler Toledo Instruments Co., Ltd., Shanghai, China).

\subsection{Reagents}

Zihua snap bean (P. vulgaris) seeds were from Harbin Xiangfang District Gongbin Seed Company (Harbin, China). A 2\% rabbit red blood cell suspension was obtained from Beijing Baiaolaibo Technology Co., Ltd. (Beijing, China). All the chemicals were obtained from Aladdin (Shanghai, China) and were of analytical grade, and all the solutions were prepared using ultrapure water obtained from Northeast Agricultural University.

\subsection{Extraction and Purification of Zihua Snap Bean Lectin}

Dried Zihua snap-bean seeds were ground to a fine powder passed through a 50-mesh sieve. Then, the powder was mixed with phosphate-buffered saline (PBS, $10 \mathrm{mM}, \mathrm{pH} 7.0$ ) by agitation overnight at $4{ }^{\circ} \mathrm{C}$. Afterwards, the extract was filtered and centrifuged to get a supernatant as the crude extract. 
The crude extract was purified using the aqueous two-phase system (ATPS) method as previously described [25]. ATPS was formed by mixing $0.75 \mathrm{~g}$ of ammonium sulfate, $0.9 \mathrm{~g}$ of polyethylene glycol 600 (PEG 600), and $0.4 \mathrm{~g}$ of $\mathrm{NaCl}$, adding $1 \mathrm{~mL}$ of crude extract solutions. The total weight of the system was $5 \mathrm{~g}$ with the $\mathrm{pH}$ set on 7.5. After separation by ATPS, lectin and proteins in the top phase were collected and dialyzed against deionized water for $24 \mathrm{~h}$ by a dialysis bag with 7000-Da molecular weight cutoffs to remove salt and PEG 600.

The lectin was further purified by gel chromatography. A $10 \mathrm{mg} / \mathrm{mL}$ lectin solution was prepared by concentrating the dialyzed lectin solution and then filtering it through a $0.45-\mu \mathrm{m}$ membrane. Then, $5 \mathrm{~mL}$ of the filtered liquid was applied to a Sephadex G-75 column pre-equilibrated with the 0.02-M phosphate buffer (pH 7.2). The column was washed with eluent at a flow rate of $0.5 \mathrm{~mL} / \mathrm{min}$. The peak fraction prepared for the determination of hemagglutinating activity was collected and pooled, and then dialyzed and lyophilized to obtain lectin lyophilized powder for use.

\subsection{Determination of the Hemagglutinating Activity}

The determination of the hemagglutinating activity (HA) was performed in microtiter plates according to Jiang [25]. The lectin lyophilized powder was formulated into lectin solution $(0.5 \mathrm{mg} / \mathrm{mL})$. Then, $50 \mu \mathrm{L}$ of lectin solution was twofold serially diluted with stroke-physiological saline, and $50 \mu \mathrm{L}$ of $2 \%$ rabbit red blood cell suspension were added. The results were read after $45 \mathrm{~min}$ at room temperature, when the negative control was fully sedimented.

The sugar specificity of lectin was analyzed in a manner analogous to the hemagglutination test. The sugar base to be tested was formulated into a certain concentration of aqueous solutions. Equal volumes $(25 \mu \mathrm{L})$ of the sugar solution and the lectin solution were mixed, and stored at room temperature for $1 \mathrm{~h}$. Then, the mixed solutions were diluted to detect hemagglutinating activity. Water was set as a blank control to observe the inhibition of the lectin hemagglutinating activity by different glycosyl groups. Each experiment was repeated three times.

\subsection{The Properties Experiment of the Zihua Snap Bean Lectin}

\subsubsection{Metal Ions Dependence}

The lyophilized powder of the Zihua snap bean lectin was dissolved in $10 \mathrm{mmol} / \mathrm{L}$ phosphate buffer ( $\mathrm{pH} 7.2$ ) to prepare a lectin solution of $0.5 \mathrm{mg} / \mathrm{mL}$, and the hemagglutinating activity of lectin solution was determined. Lectin solution was dialyzed in a phosphate buffer solution $(10 \mathrm{mmol} / \mathrm{L}$, pH 7.2) containing $50 \mathrm{mmol} / \mathrm{L}$ ethylenediaminetetraacetic acid (EDTA) until no hemagglutinating activity was detected. Then, it was dialyzed against phosphate buffer solution to remove EDTA, and the obtained sample solution was subjected to a hemagglutinating activity analysis to confirm that the hemagglutinating activity was lost. Lectin solution without hemagglutinating activity was mixed with different metal salt solutions $(100 \mathrm{mmol} / \mathrm{L})$, and then diluted to detect hemagglutinating activity to study the effect of metal salt ions on the recovery of hemagglutinating activity. Each experiment was repeated three times.

\subsubsection{Thermal Stability of Zihua Snap Bean Lectin}

A thermal stability experiment followed He's method with minor modification [29]. The method of lectin solution configuration was the same as in Section 2.5.1. The lectin solution in 10-mL centrifuge tubes was heated to the desired temperature using a constant temperature water bath. All the tubes were completely submerged in the water bath throughout the investigation and ensured to prevent the evaporation of water or loss of solution. A series of thermal treatments were carried out at $50{ }^{\circ} \mathrm{C}, 60^{\circ} \mathrm{C}$, $70{ }^{\circ} \mathrm{C}, 80^{\circ} \mathrm{C}$, and $90^{\circ} \mathrm{C}$ for $0 \mathrm{~min}, 5 \mathrm{~min}, 10 \mathrm{~min}, 15 \mathrm{~min}, 20 \mathrm{~min}, 25 \mathrm{~min}$, and $30 \mathrm{~min}$. At the end of the thermal treatment, it was immediately cooled in cold water and stored at $4{ }^{\circ} \mathrm{C}$ until further analysis. 


\subsection{3. pH Stability of Zihua Snap Bean Lectin}

The lectin lyophilized powder was dissolved in buffers of desired $\mathrm{pH}$ to formulate a solution of $0.5 \mathrm{mg} / \mathrm{mL}$. After standing at $4{ }^{\circ} \mathrm{C}$ for $12 \mathrm{~h}$, the acid-base stability of the lectin was studied by a hemagglutinating experiment and fluorescence spectroscopy, respectively. Glycine- $\mathrm{HCl}$ buffer solution at $\mathrm{pH}$ 2.0, citrate buffer solution at $\mathrm{pH} 3.0$ to 5.0, phosphate buffer at $\mathrm{pH} 6.0$ to 8.0, and glycine-sodium hydroxide buffer solution at $\mathrm{pH} 9.0$ to 11.0 were used to maintain the $\mathrm{pH}$.

\subsubsection{In Vitro Digestion Assay of Zihua Snap Bean Lectin}

Simulated gastric fluid (SGF) was prepared according to He [21], which consisted of $2.0 \mathrm{~g} / \mathrm{L}$ of $\mathrm{NaCl}$ and $3.2 \mathrm{~g} / \mathrm{L}$ of pepsin. The $\mathrm{pH}$ value of the SGF solution was adjusted to 1.2 with hydrochloric acid. Lectin solution $(5 \mathrm{mg} / \mathrm{mL})$ was mixed with the SGF solution ( $\mathrm{pH} 1.2)$ in a water bath at $37^{\circ} \mathrm{C}$ to start the digestion reaction. The pepsin reaction was terminated by adding $\mathrm{Na}_{2} \mathrm{CO}_{3}$ solution with a $\mathrm{pH}$ of 11.0 after $0 \mathrm{~min}, 10 \mathrm{~min}, 20 \mathrm{~min}, 30 \mathrm{~min}, 40 \mathrm{~min}, 50 \mathrm{~min}$, and $60 \mathrm{~min}$, respectively.

Simulated intestinal fluid (SIF) was prepared according to He [21] with minor modifications. First, $10 \mathrm{~g}$ of trypsin and $6.8 \mathrm{~g}$ of $\mathrm{KH}_{2} \mathrm{PO}_{4}$ were dissolved in a moderate amount of water. The $\mathrm{pH}$ was adjusted to 6.8 with $0.2 \mathrm{~mol} / \mathrm{L} \mathrm{NaOH}$ solution or $0.2 \mathrm{~mol} / \mathrm{L}$ hydrochloric acid solution, and then diluted to $1000 \mathrm{~mL}$ with water. Then, the test lectin solution $(5 \mathrm{mg} / \mathrm{mL})$ was mixed with the SIF solution ( $\mathrm{pH}$ 6.8) in a water bath to start the tryptic digestion reaction. The trypsin reaction was immediately terminated by heating to boiling after a certain time.

\subsubsection{Antibacterial Experiment of Zihua Snap Bean Lectin}

Antibacterial activity was investigated by the disc diffusion method [30]. S. aureus, E. coli, and B. subtilis were used. Bacteria were grown in shaker flasks containing potato medium and placed at $28^{\circ} \mathrm{C}$ for $24 \mathrm{~h}$. After diluted to $10^{7}$ colony-forming units $/ \mathrm{mL}(\mathrm{CFU} / \mathrm{mL}), 100 \mu \mathrm{L}$ of bacterial suspension was smeared onto the surface of an inoculated medium. Four filter papers with diameters of $5 \mathrm{~mm}$ were placed on the surface of the inoculated medium of the plate. Then, $20 \mu \mathrm{L}$ of lectin solution with concentrations of $0.5 \mathrm{mg} / \mathrm{mL}, 1 \mathrm{mg} / \mathrm{mL}$, and $2.5 \mathrm{mg} / \mathrm{mL}$ was added to the filter papers, respectively. A stroke-physiological saline solution was used as a blank control. Then, $20 \mu \mathrm{L}$ of phenol solution with concentrations of $0.5 \mathrm{mg} / \mathrm{mL}, 1 \mathrm{mg} / \mathrm{mL}$, and $2.5 \mathrm{mg} / \mathrm{mL}$ was used as a positive control. After being incubated at $28^{\circ} \mathrm{C}$ for $12 \mathrm{~h}$, the plate was taken out for observation and recording. A transparent ring around the filter paper revealed antimicrobial activity.

\subsubsection{Antifungal Experiment of Zihua Snap Bean Lectin}

P. infestans was carried out in a petri plate containing tomato juice agar and incubated in a dark incubator at $22{ }^{\circ} \mathrm{C}$ for seven days. After the mycelial colony had developed, two filter papers with diameters of $5 \mathrm{~mm}$ were placed in front of the mycelial colony. Then, $20 \mu \mathrm{L}$ of lectin solution $(5 \mathrm{mg} / \mathrm{mL})$ and $20 \mu \mathrm{L}$ of stroke-physiological saline solution were added to the two filter papers, respectively. The plate was incubated at $22{ }^{\circ} \mathrm{C}$ for seven days and taken out of the plate for observation.

\subsection{Electrophoresis}

SDS-PAGE was used to identify lectin and evaluate the digestion of lectin by $12 \%$ bis-acrylamide homogeneous gel. The gel was run for 95 min using TRIS-glycine-SDS running buffer at constant voltages of $80 \mathrm{~V}$ for the stacking gel and $120 \mathrm{~V}$ for the separating gel. After the electrophoresis was run, the gel was washed with several volumes of distilled water for several times, and then stained for 30 min with Coomassie brilliant blue R-250 and destained with destaining solution.

\subsection{Nano LC-ESI-MS/MS Analysis}

NanoLC-ESI-MS/MS analysis of the digested lectin sample was carried out by a high-pressure liquid chromatography (HPLC) system (Agilent, Palo Alto, CA, USA) with an Agilent C18 column 
(75 $\mu \mathrm{m} \times 8 \mathrm{~cm}, 3 \mu \mathrm{m})$. Mobile phase A consisted of $97.5 \%$ water, $2 \%$ acetonitrile, and $0.5 \%$ formic acid, whereas mobile phase B consisted of $9.5 \%$ water, $90 \%$ acetonitrile, and $0.5 \%$ formic acid. The gradation time from $2 \%$ mobile phase B to $90 \%$ mobile phase B was $60 \mathrm{~min}$, plus $20 \mathrm{~min}$ for sample loading and $20 \mathrm{~min}$ for column washing. The injection volume was $3 \mu \mathrm{L}$. The HPLC system was online coupled with a linear ion trap mass spectrometer (LTQ, Thermo, San Diego, CA, USA) in a way that a sample eluted from an HPLC column was directly ionized by an electrospray ionization (ESI) process and entered into the mass spectrometer. The ionization voltage was often optimized in the instrument-tuning process, and normally in a range of $1.5 \mathrm{kv}$ to $1.8 \mathrm{kv}$. The capillary temperature was set at $100{ }^{\circ} \mathrm{C}$. The mass spectrometer was set at the data-dependent mode to acquire MS/MS data via a low-energy collision-induced dissociation (CID) process. The default collision energy was $33 \%$, and the default charge state was three. One full scan with one microscan with a mass range of $350 \mathrm{amu}$ to 1650 amu was acquired, followed by nine MS/MS scans of the nine most intense ions with a full mass range and three microscans. The dynamic exclusion feature was set as following: repeat count of one and an exclusion duration of $1 \mathrm{~min}$. The exclusion width was $4 \mathrm{Da}$. The mass spectrometric data was used to search against the most recent non-redundant protein database (NR database, NCBI (Wellington, DE, USA)) with ProtTech's ProtQuest (Philadelphia, PA, USA) software suite.

\subsection{Fourier Transform Infrared Sectroscopy}

The infrared spectrum of the Zihua snap bean lectin was obtained with a Fourier transform infrared spectrometer (Shimadzu, Kyoto, Japan) within the wave number range of 400 to $4000 \mathrm{~cm}^{-1}$. First, $2 \mathrm{mg}$ of the tested lectin lyophilized powder were ground together with $20.0 \mathrm{mg}$ of spectroscopic grade $\mathrm{KBr}$ powder and pressed into a 1-mm pellet. The experiment was repeated three times. The spectra was processed using Peakfit v4.12 software (SeaSolve, San Jose, CA, USA).

\subsection{Fluorescence Spectroscopy}

The lectin lyophilized powder was dissolved in $10 \mathrm{mmol} / \mathrm{L}$ of phosphate buffer $(\mathrm{pH} 7.2)$ and measured with a fluorescence spectrometer (PerkinElmer LS55, Fremont, CA, USA) at fluorescence excitation wavelengths of $280 \mathrm{~nm}$ and $295 \mathrm{~nm}$, respectively. The emission spectrum were recorded between $300-400 \mathrm{~nm}$. The slit widths of the excitation and emission monochromators were set to $5 \mathrm{~nm}$. Fluorescence spectral baseline subtraction was performed using a sample buffer system as a blank control.

\subsection{Statistical Analysis}

The data were expressed as the mean or the percent mean \pm standard deviation (SD). All the experiments were tested and analyzed in triplicate. An analysis of variance (ANOVA) was identified to determine the significant differences $(P<0.05)$ between means.

\section{Results and Discussion}

\subsection{Purification of Zihua Snap Bean Lectin}

The elution curve of the lectin purified by a two-step method based on an aqueous two-phase system and Sephadex G-75 column was shown in Figure 1. As indicated in Figure 1, two peaks could be obtained on the elution curve. Solutions corresponding to the two peaks were collected for the hemagglutinating test, and it was found that the solution that corresponded to peak 1 showed hemagglutinating activity, while the solution that corresponded to peak 2 did not. The active solution was collected and dialyzed to remove salts, and then subjected to SDS-PAGE. The electrophoresis result is shown in Figure 2. 


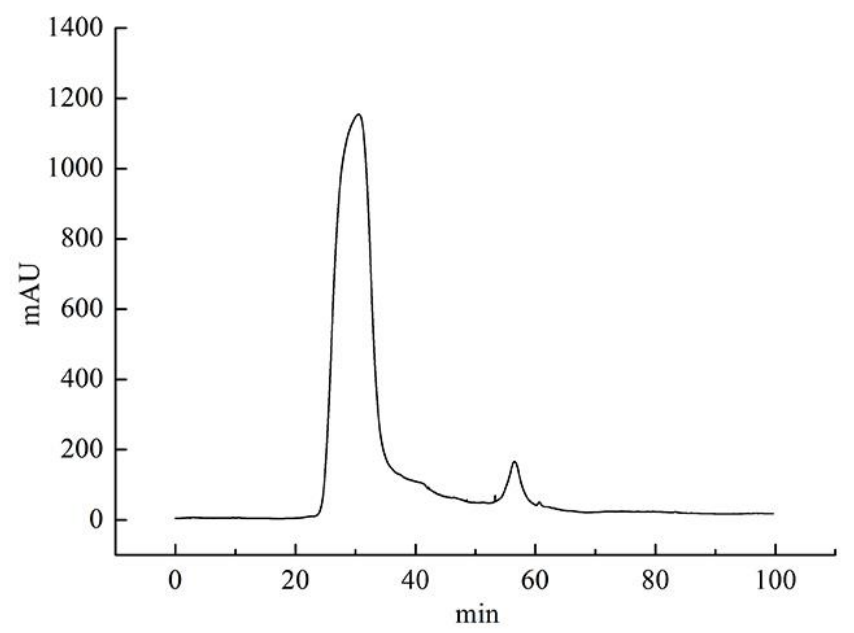

Figure 1. Gel chromatography of lectin extracted by an aqueous two-phase system (ATPS) on Sephadex G-75.

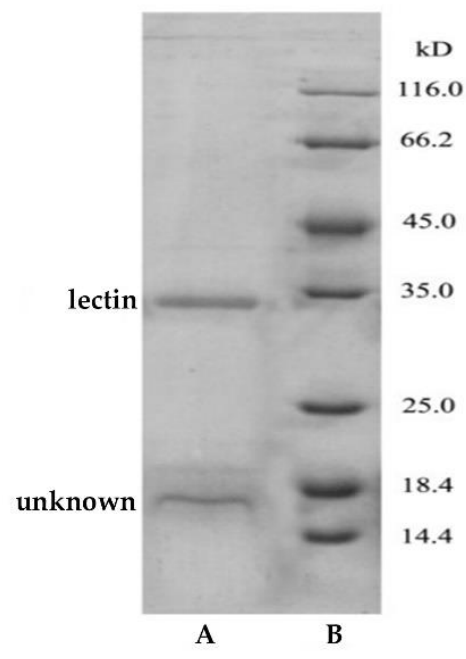

Figure 2. SDS-PAGE of the lectin after Sephadex G-75 purification: A, sample; B, marker.

As indicated in Figure 2, a band (lectin tape) at $35 \mathrm{kDa}$ and a band (unknown tape) at $18.4 \mathrm{kDa}$ were found in the SDS-PAGE of the lectin after Sephadex G-75. The SDS-PAGE suggested that the lectin existed as a monomer with a molecular weight of about $35 \mathrm{kDa}$, which is similar to that obtained by Jiang [25]. It was conjectured that the band of $18.4 \mathrm{kDa}$ might be due to the partial dissociation of the lectin subunit. Compared to the band at $18.4 \mathrm{kDa}$, the band at $35 \mathrm{kDa}$ may be due to the incomplete unfolding of the non-aggregated lectin that occurs in the presence of SDS denaturing conditions [31]. The band, unknown tape, at $18.4 \mathrm{kDa}$ was not sure. We defined it as an unknown sample for mass spectrometric analysis.

\subsection{Identification of Zihua Snap Bean Lectin by Tandem Mass Spectrometry}

The lectin sample tape and the unknown sample tape in Section 3.1 were subjected to liquid chromatography-nano electrospray ionization mass spectrometry (Nano LC-ESI-MS/MS), respectively.

\subsubsection{Lectin Tape Analysis}

The database UniProt was used to analyze the peptides hydrolyzed by sequencing grade modified trypsin (Promega). The molecular weight of the Zihua snap bean lectin was 29,742.25 Da, and its relative abundance was $57.3 \%$. There were also other proteins, most of which were undetermined, as 
shown in Table 1. In addition, a few were $\alpha$-amylase inhibitors with a molecular weight of $27,190.47$ Da and a relative abundance of $6.1 \%$.

Table 1. The test results of the lectin sample by liquid chromatography-nano electrospray ionization mass spectrometry (Nano LC-ESI-MS/MS).

\begin{tabular}{ccccc}
\hline Hits & Protein Molecular Weight/Da & Number of Peptides & Link & Relative Abundance \\
\hline 1 & $29,742.25$ & 246 & Q8RVX6 & $57.3 \%$ \\
2 & $39,105.93$ & 65 & V7BFT4 & $8.6 \%$ \\
3 & $35,564.65$ & 56 & V7AIB2 & $10.8 \%$ \\
4 & $27,190.47$ & 27 & P02873 & $6.1 \%$ \\
5 & $36,314.02$ & 26 & V7BPP1 & $2.9 \%$ \\
6 & 97,527 & 26 & V7BX14 & $1.6 \%$ \\
7 & $97,769.06$ & 23 & V7BZK0 & $0.6 \%$ \\
8 & $71,495.53$ & 20 & V7C9P5 & $0.1 \%$ \\
\hline
\end{tabular}

Figure 3 showed the peptides in the Zihua snap bean lectin. As indicated in Figure $3 b$, the peak $m / z 855.49$ was the strong peak of the y cleavage peptide GLFNNYK, while the peak $\mathrm{m} / \mathrm{z} 685.40$ was the stronger peak of the y cleavage peptide FNNYK. The peak $m / z 511.32$ was the weaker peak of the $\mathbf{b}$ cleavage peptide GGLLG. The peak $\mathrm{m} / \mathrm{z} 227.98$, the peak $\mathrm{m} / \mathrm{z} 341.25$, the peak $\mathrm{m} / \mathrm{z} 658.41$, and the peak $\mathrm{m} / z 1049.44$ corresponded to the b cleavage peptides GGL, GGLL, and GGLLGLFNNY, respectively. The peak $m / z 798.48$ and the peak $m / z 968.57$ were y cleavage peptides LFNNYK and LGLFNNYK, respectively. As shown in Figure 3d, the peak $m / z 856.48[\mathrm{M}+\mathrm{H}]+$ was the stronger peak of the $y$ cleavage peptide, GLFNNYK, and the peak $m / z 686.31[\mathrm{M}+\mathrm{H}]+$ was stronger peak of the $y$ cleavage peptide, FNNYK. The identified peptides of the Zihua snap bean lectin are shown in Table 2, which indicated that the peptides of the two primary cleavages of lectin were GGLLGLFNNYK and DKGGLLGLFNNYK, respectively. The two peptides had overlapping portions to obtain a complete amino acid sequence, which proves that the protein was a lectin.

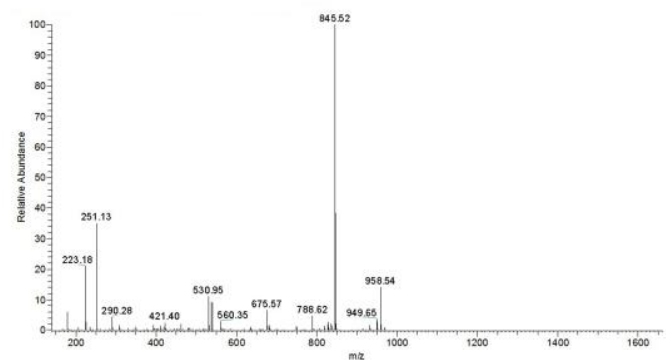

(a)

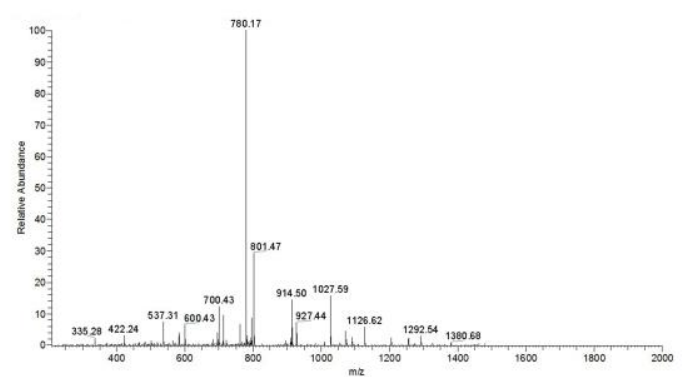

(c)

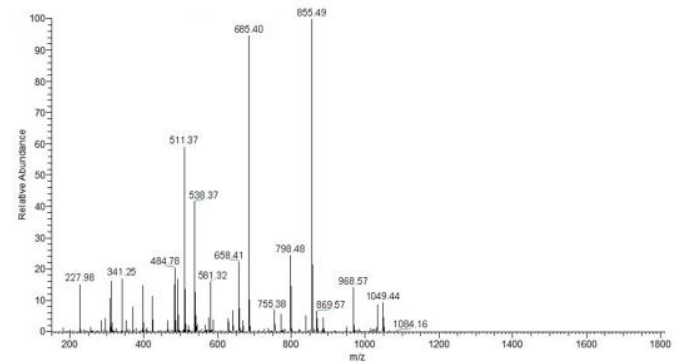

(b)

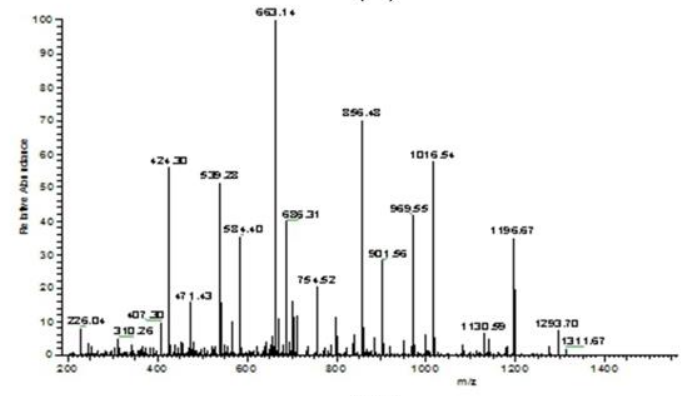

(d)

Figure 3. Two level mass spectrometry of the Zihua snap bean lectin (a) HIGIDVNSIK, (b) GGLLGLFNNYK, (c) GENAEVLITYDSSTK, and (d) DKGGLLGLFNNYK. 
Table 2. The peptide of the Zihua snap bean lectin as determined by Nano LC-ESI-MS/MS.

\begin{tabular}{ccc}
\hline Peptide Number & Amino Acid Sequence & $m / z$ \\
\hline 6046 & HIGIDVNSIK & 1094.61 \\
6339 & TTTWDFVK & 996.49 \\
6350 & LTNVNDNGEPTLSSLGR & 1785.89 \\
7217 & DKGGLLGLFNNYK & 1437.76 \\
7269 & GNVETNDVLSWSFASK & 1752.83 \\
7304 & YDSNAHTVAVEFDTLYNVHWDPKPR & 2973.40 \\
7329 & GGLLGLFNNYK & 1194.64 \\
7503 & TTTWDFVKGENAEVLITYDSSTK & 2604.26 \\
8487 & SVLPEWVIVGFTATTGITK & 2018.11 \\
8669 & YDSNAHTVAVEFDTLYNVHWDPK & 2720.25 \\
8877 & LSDGTTSEALNLANFALNQIL & 2204.13 \\
9249 & LLVASLVYPSLK & 1301.80 \\
11054 & DKGGLLGLFNNYK & 1437.76 \\
\hline
\end{tabular}

\subsubsection{Unknown Sample Tape Analysis}

The results of Table 3 showed that $34.4 \%$ of relative abundance was still a lectin with a molecular weight of $29,742.25 \mathrm{Da}$, meaning that unknown sample band with $18 \mathrm{KDa}$ was due to the partial dissociation of the lectin subunit.

Table 3. The test results of unknown sample by Nano LC-ESI-MS/MS.

\begin{tabular}{ccccc}
\hline Hits & Protein Molecular Weight/Da & Number of Peptides & Login ID & Relative Abundance \\
\hline 1 & $29,742.25$ & 104 & gi $|19773404|$ & $34.4 \%$ \\
2 & $24,778.15$ & 48 & gi $|2780981|$ & $18.4 \%$ \\
3 & $50,723.5$ & 29 & gi $|75708857|$ & $3.1 \%$ \\
4 & $49,241.02$ & 25 & gi $|130169|$ & $2.8 \%$ \\
5 & $49,483.71$ & 19 & gi $|351727923|$ & $0.3 \%$ \\
6 & $71,980.77$ & 17 & gi $|356500683|$ & $0.4 \%$ \\
7 & $97,136.89$ & 16 & gi $|351727843|$ & $1.1 \%$ \\
8 & $47,824.05$ & 15 & gi|374297913| & $0.7 \%$ \\
\hline
\end{tabular}

It could be obtained from Tables 2 and 4 that the identified peptides in the unknown samples had fewer species than the identified peptides in the lectin samples. Nano LC-ESI-MS/MS mass spectrometry showed that the molecular weight of the Zihua snap bean lectin was 29,742.25 Da, and the two-step method based on an aqueous two-phase system and Sephadex G-75 was suitable to separate and purify lectin.

Table 4. The peptide of the lectin in an unknown sample as determined by Nano LC-ESI-MS/MS.

\begin{tabular}{ccc}
\hline Peptide Number & $m / z$ & Amino Acid Sequence \\
\hline 6346 & 1094.61 & HIGIDVNSIK \\
6451 & 1785.89 & LTNVNDNGEPTLSSLGR \\
6580 & 996.49 & TTTWDFVK \\
6741 & 1246.67 & FNETNLILQR \\
6991 & 1323.69 & TSFIVSDTVDLK \\
7279 & 1752.83 & GNVETNDVLSWSFASK \\
7326 & 1437.76 & DKGGLLGLFNNYK \\
7410 & 1301.80 & LLVASLVYPSLK \\
7444 & 2973.40 & YDSNAHTVAVEFDTLYNVHWDPKPR \\
7496 & 1194.64 & GGLLGLFNNYK \\
8307 & 2018.11 & SVLPEWVIVGFTATTGITK \\
8634 & 2204.13 & LSDGTTSEALNLANFALNQIL \\
\hline
\end{tabular}




\subsection{The Properties of Zihua Snap Bean Lectin}

\subsubsection{Carbohydrate Specificity of Zihua Snap Bean Lectin}

Glucose, fructose, sucrose, D-maltose, D-trehalose, $N$-acetyl-D-glucosamine, $N$-acetyl-D-galactosamine, D-galactose, and lactose were used to study the carbohydrate specificity of the Zihua snap bean lectin. None of the nine glycosyl groups tested could inhibit the hemagglutinating activity of the Zihua snap bean lectin. Consistent with the result, d-fructose, d-glucose, and sucrose failed to inhibit the hemagglutinating activity of deep red kidney bean lectin [23]. As for Hypsizigus marmoreus lectin, glucose, mannose, L-fucose, and lactose had no inhibitory effect [32]. According to related literature, the glycosyl group specifically bound by some of the bean lectin is a polysaccharide with a larger molecular weight than a monosaccharide or oligosaccharide [33].

\subsubsection{Metal Ions' Dependency of Zihua Snap Bean Lectin}

It was confirmed that certain metal ions played a key role in maintaining the stability of the lectin structure and maintaining its specific biological activity [34]. Ethylenediaminetetraacetic acid (EDTA) is a divalent metal ion-chelating agent. When the lectin fully reacted with EDTA, the hemagglutinating activity of lectin was lost, and the reaction was generally reversible [35].

After fully reacting with EDTA, the hemagglutinating activity of the lectin was completely lost. The effect of metal ions on the recovery of the hemagglutinating activity was studied by adding different metal ions containing $\mathrm{Cu}^{2+}, \mathrm{Na}^{+}, \mathrm{Mn}^{2+}, \mathrm{Ba}^{2+}, \mathrm{Mg}^{2+}, \mathrm{K}^{+}, \mathrm{Fe}^{2+}, \mathrm{Fe}^{3+}$, and $\mathrm{Ca}^{2+}$. The results showed that $\mathrm{Cu}^{2+}, \mathrm{Na}^{+}, \mathrm{Ba}^{2+}, \mathrm{K}^{+}, \mathrm{Fe}^{2+}$, and $\mathrm{Fe}^{3+}$ ions had no effect on restoring the hemagglutinating activity of the lectin. Meanwhile, among the ions that could restore the Zihua snap bean lectin activity, $\mathrm{Mn}^{2+}$ and $\mathrm{Ca}^{2+}$ ions could completely restore the hemagglutinating activity of the lectin, while $\mathrm{Mg}^{2+}$ ions could only partially restore the activity. Some researchers indicated that the agglutinating activity of Inocybe umbrinella lectin was inhibited by $\mathrm{Ca}^{2+}, \mathrm{Mg}^{2+}$, and $\mathrm{Mn}^{2+}$ ions, but was unaffected by $\mathrm{Fe}^{3+}$ ions [36]. In addition, $\mathrm{Ca}^{2+}$ ions showed a significant effect on the agglutinating activity of lectin from Laetiporus sulphureus mushroom [37]. It could be concluded that $\mathrm{Mn}^{2+}$ and $\mathrm{Ca}^{2+}$ ions were essential metal ions of the Zihua snap bean lectin and played an important role in maintaining its biological activity, while $\mathrm{Mg}^{2+}$ ions could play a certain substitution role. Previous studies indicated that when $\mathrm{Mn}^{2+}$ and $\mathrm{Ca}^{2+}$ ions in proteins were chelated with EDTA, the protein conformation of lectin gradually changed to an open conformation. When a specific metal ion recombines with a lectin, the lectin slowly changed to a binding conformation. The change of binding conformation and open conformation was a cis-trans isomerization process, and the biological activity of lectin depended on the resulting conformations [26].

\subsubsection{Thermal Stability of the Zihua Snap Bean Lectin}

\subsubsection{Infrared Analysis}

FTIR was used to study the changes of the secondary structure of the Zihua snap bean lectin during thermal treatment. The second derivative of the amide I region of the lectin treated at different temperatures $\left(70{ }^{\circ} \mathrm{C}, 80^{\circ} \mathrm{C}, 90^{\circ} \mathrm{C}\right.$, and $\left.100^{\circ} \mathrm{C}\right)$ was found, and the Gauss peak shape was used for fitting. Different bands that overlapped together were analyzed, and the results are shown in Figure 4.

The corresponding relationship between each sub-peak and secondary structure meant that $\sim 1610-1642 \mathrm{~cm}^{-1}$ was a $\beta$-fold structure; $\sim 1642-1650 \mathrm{~cm}^{-1}$ was an irregular curly structure; $\sim 1650-1660 \mathrm{~cm}^{-1}$ was an $\alpha$-helix structure; $\sim 1660-1680 \mathrm{~cm}^{-1}$ was the $\beta$-turn structure; and $\sim 1680-1700 \mathrm{~cm}^{-1}$ was the $\beta$-reverse structure [38]. According to the corresponding relationship, the relative percentages of various secondary structures of lectin were obtained. As shown in Table 5 , in the unheated lectin, the $\beta$-fold was the most abundant secondary structures, with the relative percentages of $40.43 \%$. As the temperature increased, the $\alpha$-helix content decreased, while the irregular curl content increased, and the most significant change 
was obtained at $90^{\circ} \mathrm{C}(p<0.05, \mathrm{n}=3)$. It indicated that the lectin started to depolymerize under thermal treatment, and the random coil structure was mainly converted from the $\beta$ structure.

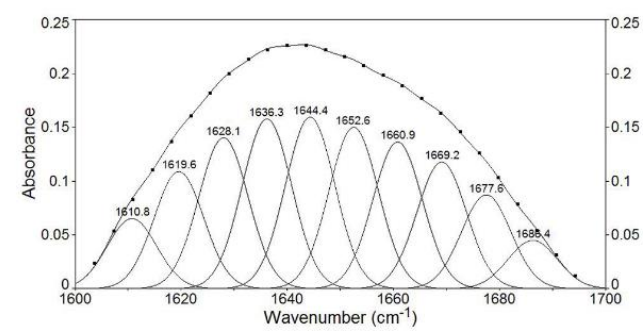

(a)

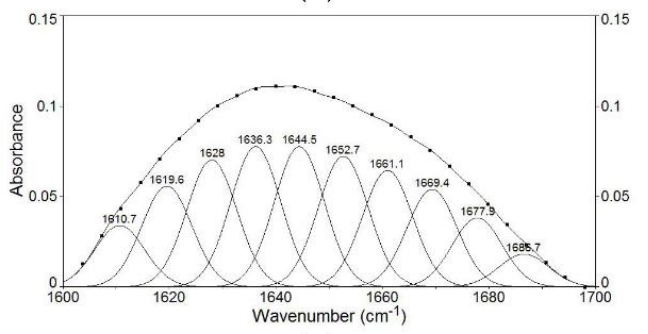

(c)

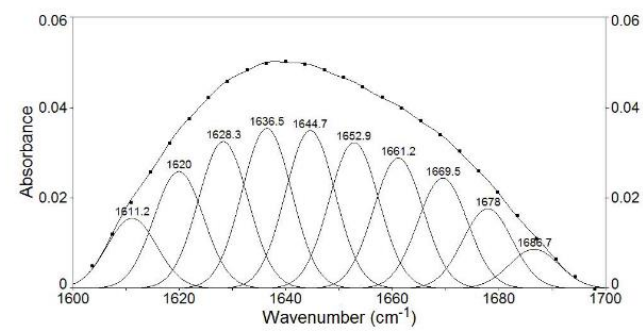

(b)

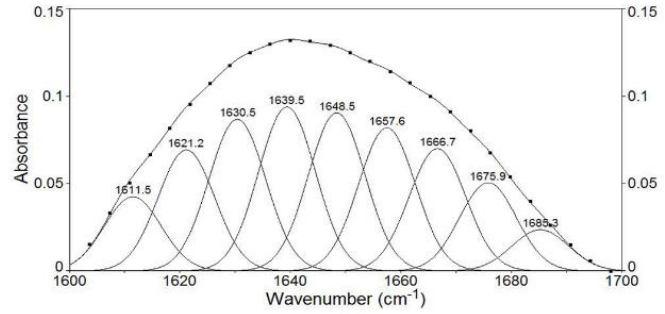

(d)

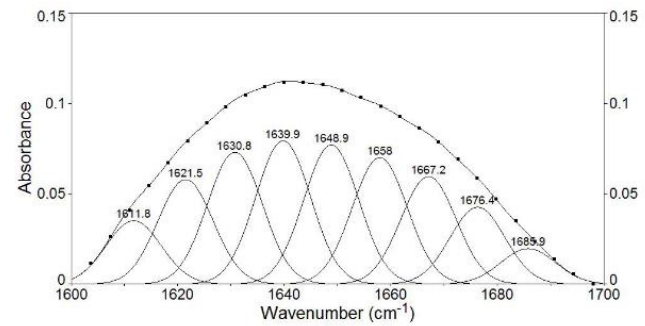

(e)

Figure 4. Second-derivative Fourier transform infrared (FTIR) spectra in the amide I region and Gaussian curve fitting of lectin at (a) room temperature, (b) $70{ }^{\circ} \mathrm{C},(\mathbf{c}) 80^{\circ} \mathrm{C}$, (d) $90^{\circ} \mathrm{C}$, and (e) $100{ }^{\circ} \mathrm{C}$.

Table 5. The content of the secondary structure of lectin at different temperature.

\begin{tabular}{cccccc}
\hline Temperature & $\alpha$-Helix & $\beta$-Fold & $\beta$-Turn & $\beta$-Reverse & Random Curl \\
\hline $25^{\circ} \mathrm{C}$ & $12.85 \pm 0.14^{\mathrm{b}}$ & $40.43 \pm 0.11^{\mathrm{a}}$ & $29.22 \pm 0.12^{\mathrm{d}}$ & $3.85 \pm 0.08^{\mathrm{c}}$ & $13.60 \pm 0.16^{\mathrm{a}}$ \\
$70^{\circ} \mathrm{C}$ & $12.84 \pm 0.13^{\mathrm{b}}$ & $42.23 \pm 0.08^{\mathrm{d}}$ & $27.68 \pm 0.17^{\mathrm{c}}$ & $3.39 \pm 0.11^{\mathrm{b}}$ & $13.64 \pm 0.15^{\mathrm{a}}$ \\
$80^{\circ} \mathrm{C}$ & $12.6 \pm 0.19^{\mathrm{b}}$ & $42.68 \pm 0.13^{\mathrm{e}}$ & $27.87 \pm 0.15^{\mathrm{c}}$ & $3.23 \pm 0.13^{\mathrm{ab}}$ & $13.69 \pm 0.08^{\mathrm{a}}$ \\
$90^{\circ} \mathrm{C}$ & $11.65 \pm 0.17^{\mathrm{a}}$ & $41.74 \pm 0.15^{\mathrm{c}}$ & $25.59 \pm 0.14^{\mathrm{b}}$ & $3.13 \pm 0.14^{\mathrm{a}}$ & $17.87 \pm 0.11^{\mathrm{b}}$ \\
$100^{\circ} \mathrm{C}$ & $11.58 \pm 0.11^{\mathrm{a}}$ & $40.76 \pm 0.19^{\mathrm{b}}$ & $23.86 \pm 0.09^{\mathrm{a}}$ & $3.82 \pm 0.17^{\mathrm{c}}$ & $19.98 \pm 0.19^{\mathrm{c}}$ \\
\hline
\end{tabular}

Note: The same letter followed by the same column means that the difference is not significant ( $p>0.05)$, and the difference between marked letters indicates that the difference is significant $(p<0.05)$.

\subsubsection{Fluorescence Spectroscopy Analysis}

Fluorescence spectroscopy could reflect the changes in the tertiary structure of proteins [39]. The maximum emission wavelength of the native lectin ( $0 \mathrm{~min}$ ) was maintained between $328-330 \mathrm{~nm}$ in Figure 5. All the tryptophan residues in lectin might be buried inside the hydrophobic cavity of the protein [29]. As shown in Figure 5a,b, when the heating time was short or the heating temperature was low, the fluorescence intensity was basically unchanged, and the hemagglutinating activity of lectin was not obviously affected (Figure 6a,b). As shown in Figure 5c-e, fluorescence intensity increased when the heating time was long or the heating temperature was high, which might be related to the thermal polymerization of lectin multimers caused by heat treatment [40]. In addition, there was a red shift in maximum emission wavelength (Figure $6 c-e$ ). It represented a change in the microenvironment of the tryptophan residue, which indicated that the tryptophan residue was transferred to a hydrophilic 
environment [41]. As the heating temperature reached $90^{\circ} \mathrm{C}$, the fluorescence intensity decreased most significantly, and the hemagglutinating activity of lectin dropped sharply, with all activity lost within $10 \mathrm{~min}$ (Figure 6e). In addition, the maximum emission wavelength of the tryptophan residue was accompanied by a further red shift to $340 \mathrm{~nm}$ (Figure 5e). The maximum emission wavelength of tryptophan residues in the hydrophilic environment was 350-360 nm. It indicated that the lectin folding structure was not fully expanded, and the lectin had good heat resistance.

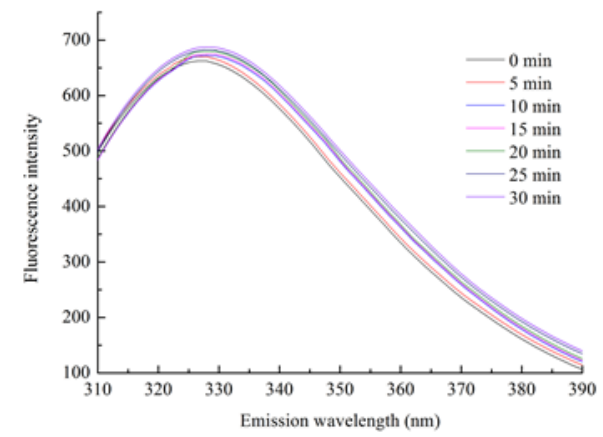

(a)

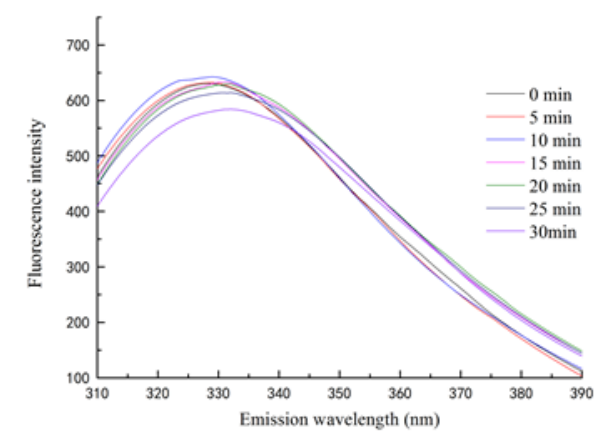

(c)

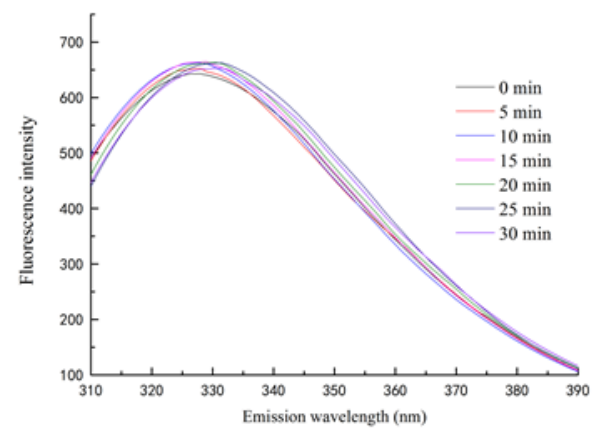

(b)

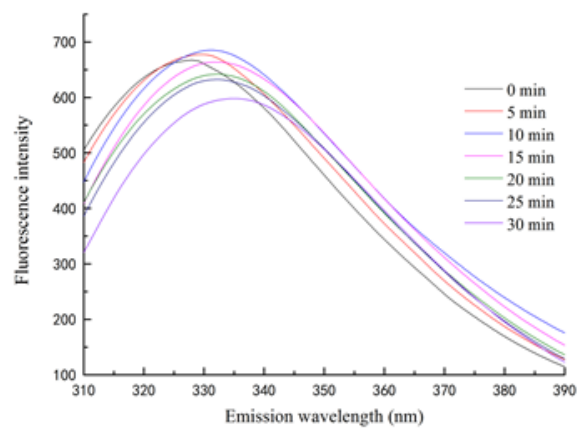

(d)

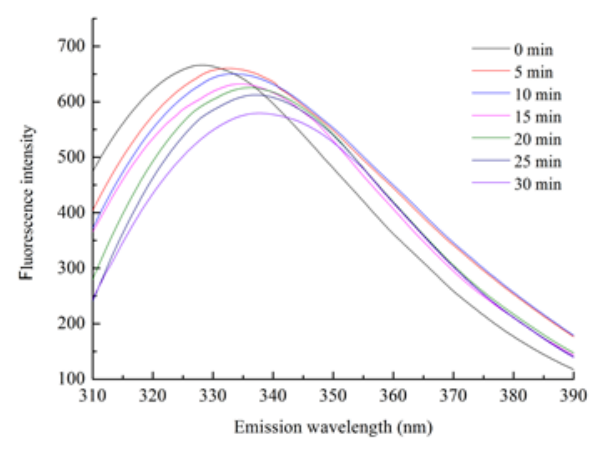

(e)

Figure 5. The intrinsic fluorescence spectra of lectin at (a) $50^{\circ} \mathrm{C},(\mathbf{b}) 60^{\circ} \mathrm{C}$, (c) $70{ }^{\circ} \mathrm{C},(\mathbf{d}) 80^{\circ} \mathrm{C}$, and (e) $90{ }^{\circ} \mathrm{C}$.

\subsection{4. pH Stability of Zihua Snap Bean Lectin}

The endogenous fluorescence of the Zihua snap bean lectin at different $\mathrm{pH}$ conditions was measured at excitation wavelengths of $280 \mathrm{~nm}$ and $295 \mathrm{~nm}$, respectively. The experimental results were shown in Figure 7. 


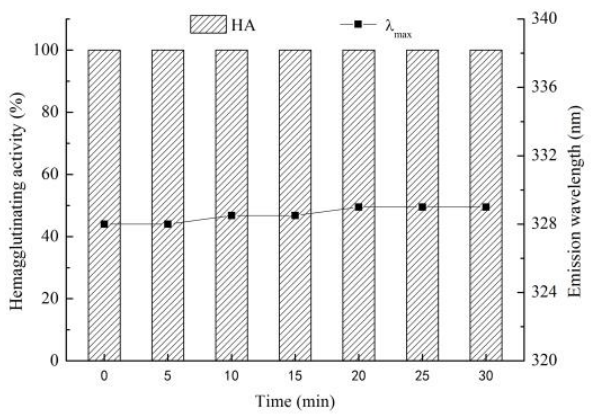

(a)

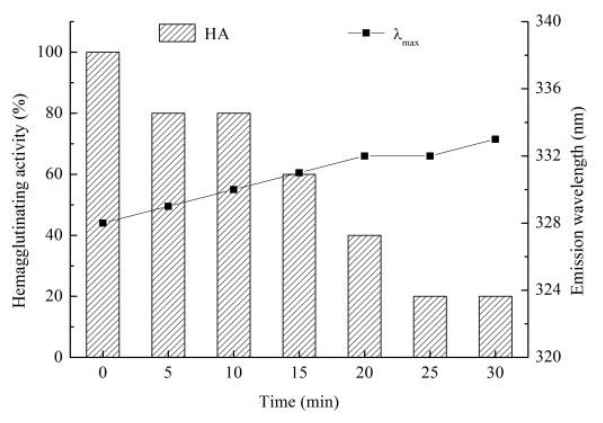

(c)

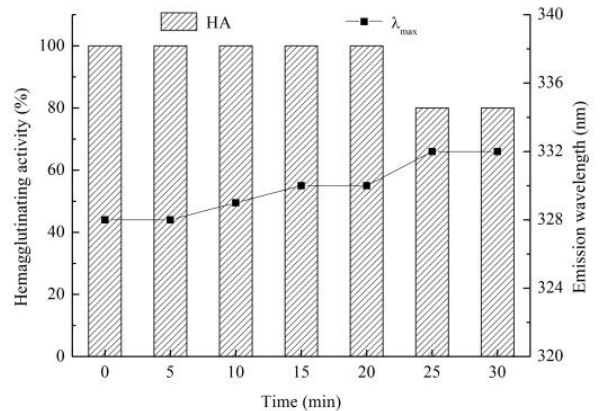

(b)

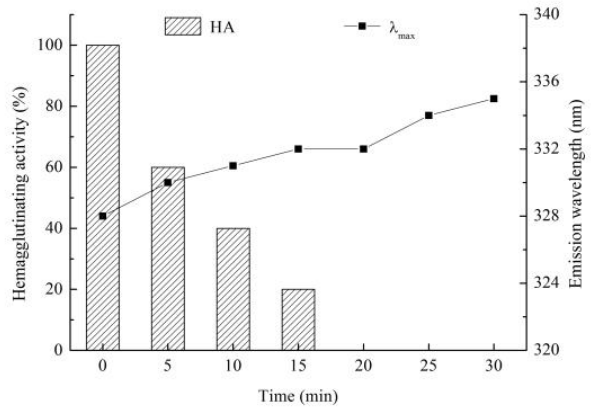

(d)

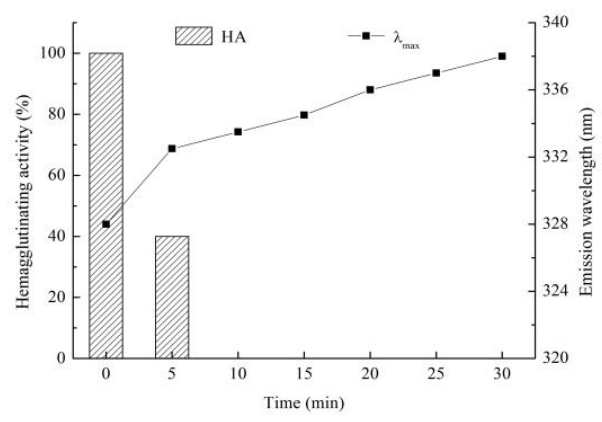

(e)

Figure 6. Hemagglutinating activity changes of lectin at (a) $50{ }^{\circ} \mathrm{C},(\mathbf{b}) 60^{\circ} \mathrm{C}$, (c) $70{ }^{\circ} \mathrm{C},(\mathbf{d}) 80{ }^{\circ} \mathrm{C}$, and (e) $90^{\circ} \mathrm{C}$.

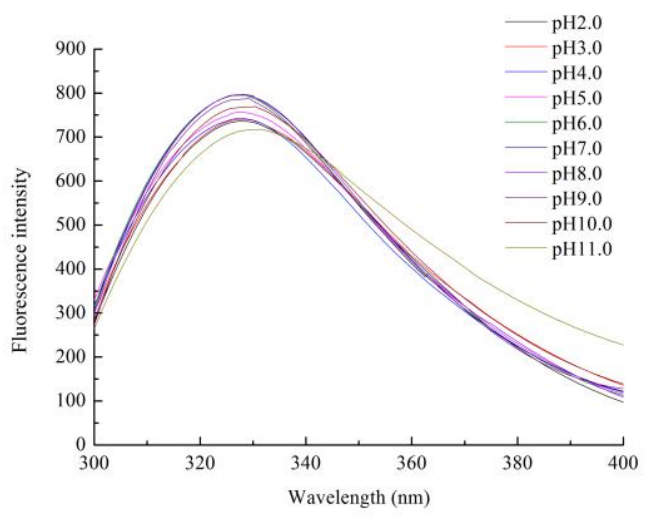

(a)

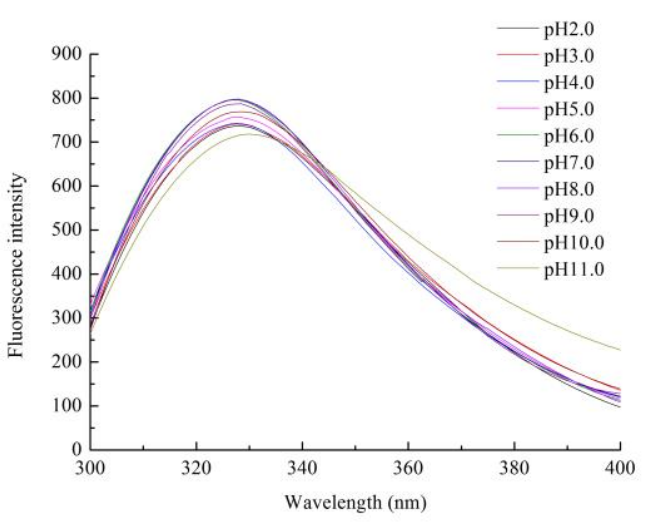

(b)

Figure 7. The emission fluorescence spectra of lectin from the Zihua snap bean at various $\mathrm{pH}$ conditions at the excitation wavelengths of (a) $280 \mathrm{~nm}$ and (b) $295 \mathrm{~nm}$. 
As shown in Figure 7a,b, as the $\mathrm{pH}$ increased in the range of 3.0 to 10.0, the fluorescence intensity gradually decreased, and the maximum absorption wavelength gradually increased. However, the change was not significant. The maximum emission wavelength of the Zihua snap bean lectin in the range of $\mathrm{pH} 3.0$ to 10.0 was $329 \pm 1.5 \mathrm{~nm}$; there were a blue shift at 2.0 and a red shift at $\mathrm{pH} 11.0$. It was indicated that most of the tryptophan residues in the lectin were in a non-polar environment. When the protein was fully expanded, the maximum emission wavelength of the exposed tryptophan residue was between 350-360 $\mathrm{nm}$. Thus, the acid-induced development of the Zihua snap bean lectin did not cause the tryptophan residue to directly contact with water. The fluorescence intensity decreased at pH 2.0 and 11.0 in Figure 7. However, it cannot be explained simply by the denaturation of proteins in acidic or alkaline environments. The reduction of fluorescence intensity at low $\mathrm{pH}$ values may be caused by fluorescence quenching or the neutralization of COO- groups on acidic amino acids near the fluorophore [40]. In general, the fluorescence spectra of nectarines had a peak shift at lower or higher $\mathrm{pH}$ conditions, and the difference in the position of the peak shift was not significant. It was indicated that the lectin structure did not show significant differences within the tested $\mathrm{pH}$ range.

Figure 8 indicates that the Zihua snap bean lectin has hemagglutinating activity in a wide $\mathrm{pH}$ range $(2.0$ to 10.0$)$. Unlike temperature and denaturant, $\mathrm{pH}$-induced protein unfolding was achieved by protonation or relatively few discrete sites of protonation [42], whereas perturbing a small number of residues did not allow the protein to fully unfold. It has been reported that lectins maintain their tertiary structure stability mainly through non-covalent forces such as hydrogen bonding, ionic interaction, hydrophobic interaction, van der Waals force, and disulfide bond covalent linkage [43]. The change in the tertiary structure of the acid-induced Zihua snap bean lectin might be due to the interaction of ions or hydrogen bonds. However, this change had no effect on the hemagglutinating activity of the lectin.

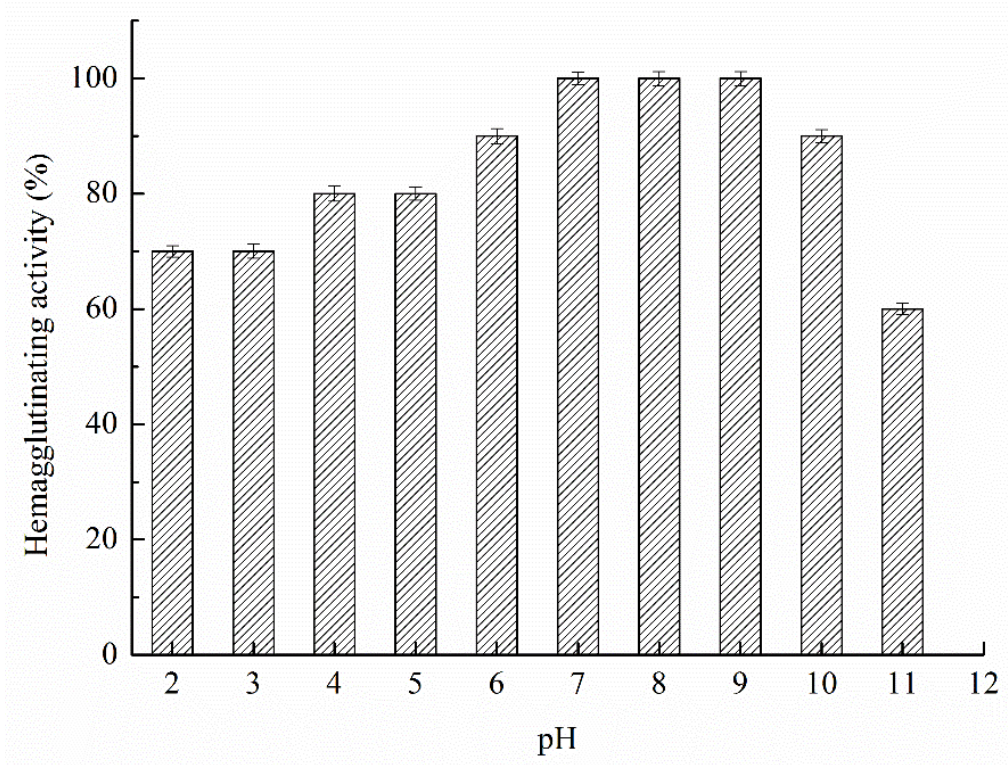

Figure 8. The hemagglutinating activity of the lectin from the Zihua snap bean at various $\mathrm{pH}$ conditions.

The $\mathrm{pH}$ stability of the Zihua snap bean lectin was studied using the denaturing agent guanidine hydrochloride $(\mathrm{GdnHCl})$. Some models suggested that $\mathrm{GdnHCl}$ could migrate to the interior of the protein to form hydrogen bonds to reduce the hydrophobic effect of the protein [44]. Under physiological conditions of $\mathrm{pH} 7.2$, the lectin reacted with different concentrations of $\mathrm{GdnHCl}$ for $24 \mathrm{~h}$. The results of the conformational changes are shown in Figure 9. The fluorescence intensity gradually decreased with the progressive increase in $\mathrm{GdnHCl}$ concentration (Figure 9a). The maximum emission wavelength of lectin did not change obviously between $0-3 \mathrm{~mol} / \mathrm{L}$ of $\mathrm{GdnHCl}$, while the maximum emission wavelength of lectin showed a significant increase between 3-6 mol/L GdnHCl (Figure 9b). When the concentration of $\mathrm{GdnHCl}$ reached $6 \mathrm{~mol} / \mathrm{L}$, the fluorescence intensity decreased by two-thirds 
compared to $0 \mathrm{~mol} / \mathrm{L}$, and the maximum emission of lectin was a red shift to $337 \mathrm{~nm}$, which was much smaller than the maximum emission wavelength $(350-360 \mathrm{~nm})$ of the tryptophan residue. It indicated that the tryptophan residue was not completely exposed to the solvent, and the folding structure of the lectin was not fully opened. The result showed that the acid-base stability of the Zihua snap bean lectin was high.

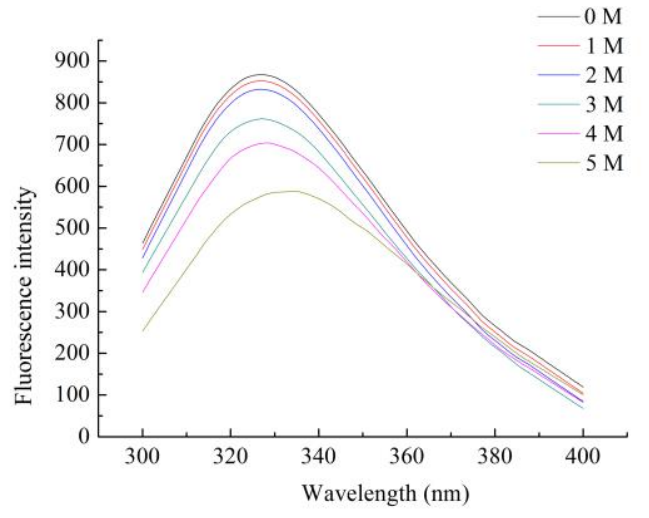

(a)

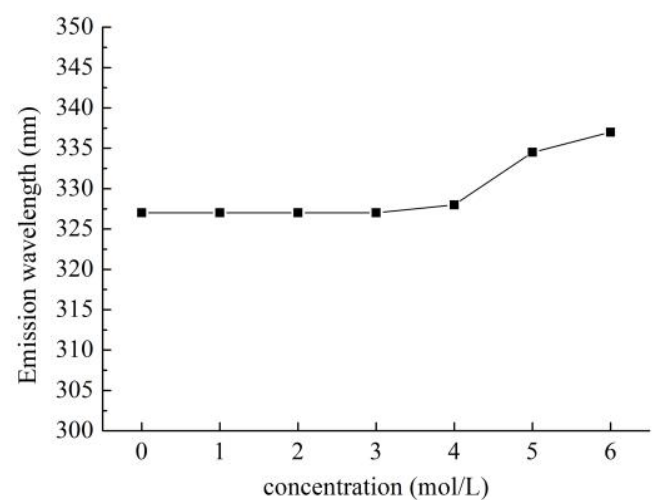

(b)

Figure 9. The fluorescence spectra (a) and maximum emission wavelength (b) of the lectin at different $\mathrm{GdnHCl}$ concentrations.

\subsection{In Vitro Studies of the Digestibility of Zihua Snap Bean Lectin}

\subsubsection{The Digestibility of Native Lectin In Vitro}

Since the Zihua snap bean lectin can agglutinate rabbit red blood cells, it is probably a sensitizing protein. Therefore, the in vitro digestion simulation experiment of the Zihua snap bean lectin was studied. SDS-PAGE has been widely used in simulated gastric fluid (SGF) analysis and simulated intestinal fluid (SIF) analysis [45]. SDS-PAGE analyses of native lectin from the Zihua snap bean in SGF and SIF are shown in Figure 10.

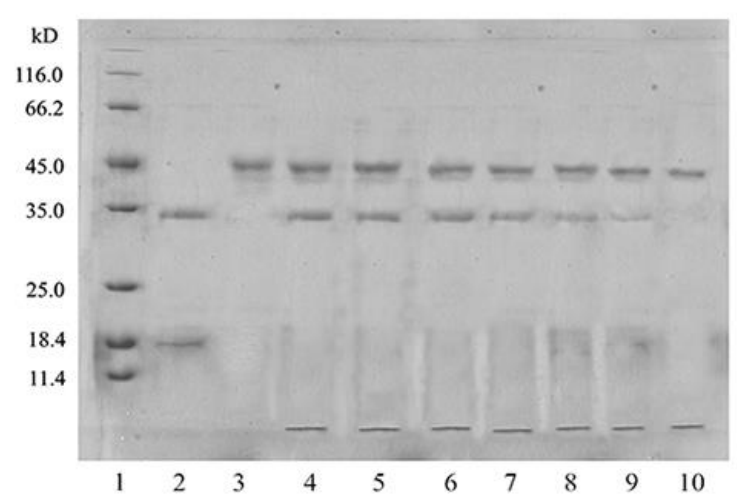

(a)

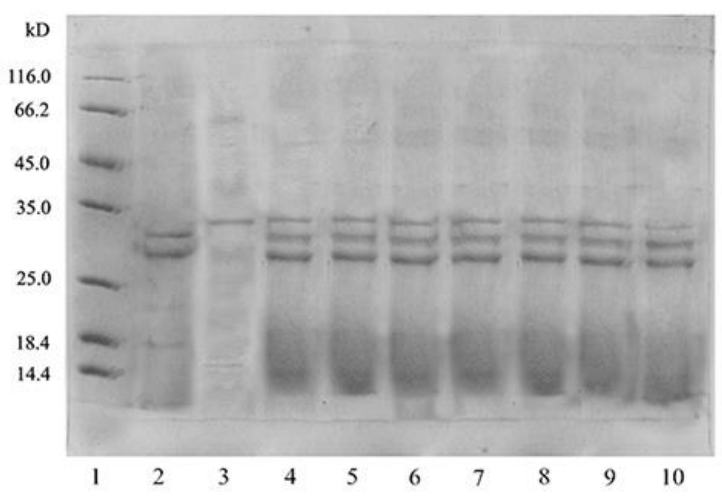

(b)

Figure 10. (a) Simulated gastric fluid (SGF) digestion profiles of the native lectin from the Zihua snap bean. In the SDS-PAGE analysis, lane 1 was the molecular weight marker, lane 2 was the native lectin, lane 3 was the pepsine, and lanes 4 to 10 were the SGF digestion pattern of the native lectin at $0 \mathrm{~min}$, $2 \mathrm{~min}, 5 \mathrm{~min}, 10 \mathrm{~min}, 20 \mathrm{~min}, 30 \mathrm{~min}$, and $60 \mathrm{~min}$. (b) Simulated intestinal fluid (SIF) digestion profiles of the native lectin from the Zihua snap bean. In the SDS-PAGE analysis, lane 1 was the molecular weight marker, lane 2 was the native lectin, lane 3 was the tryptic, and lanes 4 to 10 were the tryptic digestion pattern of the native lectin at $0 \mathrm{~min}, 10 \mathrm{~min}, 20 \mathrm{~min}, 30 \mathrm{~min}, 40 \mathrm{~min}, 60 \mathrm{~min}$, and $90 \mathrm{~min}$. 
As indicated in Figure 10a, as the digestion time prolonged, the native lectin from the Zihua snap bean was gradually decreased in SGF. It was difficult to observe the lectin band at $60 \mathrm{~min}$. The results of the in vitro simulated digestibility evaluation of food proteins indicated that most food allergens were basically stable during SGF for $60 \mathrm{~min}$ [46]. Therefore, the Zihua snap bean lectin had a certain anti-enzymatic ability in the gastrointestinal tract, which laid a foundation for the application of lectin in the field of medicine.

As shown in Figure 10b, under the tryptic digestion conditions, there was still a clear lectin fragment that remained until $90 \mathrm{~min}$. A lectin from the red kidney bean band could still be observed after $48 \mathrm{~h}$ in SIF [47]. It indicated that the native lectin had good stability. The stability of the lectin provides an estimate of whether the protein may trigger clinical symptoms of an allergic disease.

\subsubsection{The Digestibility of Thermal-Treated Lectin}

In vitro digestion experiments were performed on the preheated lectin from the Zihua snap bean. The results are shown in Figure 11.

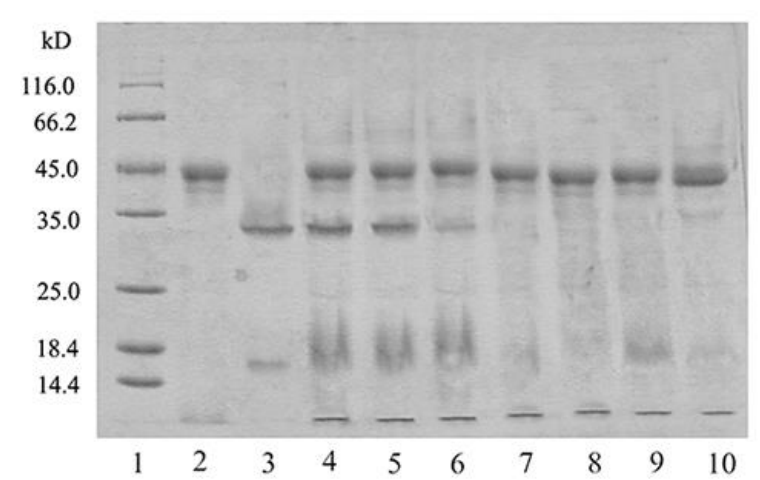

(a)

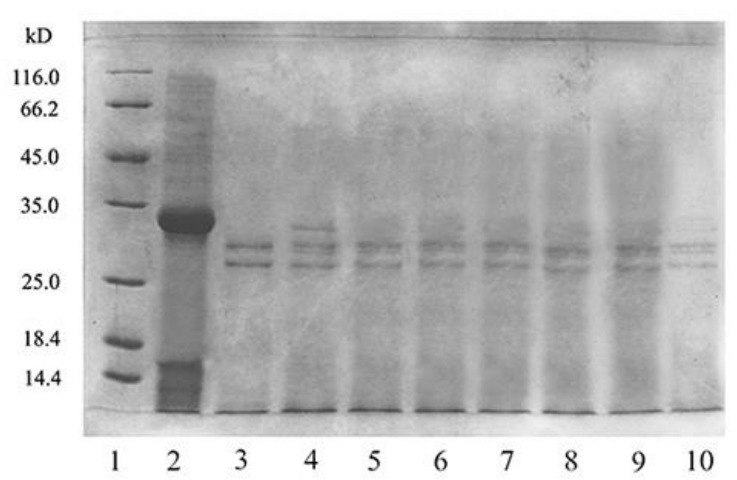

(b)

Figure 11. (a) SGF digestion profiles of the preheated lectin from the Zihua snap bean. In the SDS-PAGE analysis, lane 1 was the molecular weight marker, lane 2 was the pepsine, lane 3 was the native lectin, and lanes 4 to 10 were the SGF digestion pattern of the native lectin at $0 \mathrm{~min}, 2 \mathrm{~min}, 5 \mathrm{~min}, 10 \mathrm{~min}$, $20 \mathrm{~min}, 30 \mathrm{~min}$, and $60 \mathrm{~min}$. (b) SIF digestion profiles of the preheated lectin from the Zihua snap bean. In the SDS-PAGE analysis, lane 1 was the molecular weight marker, lane 2 was the tryptic, lane 3 was the native lectin, and lanes 4 to 10 were the tryptic digestion pattern of the native lectin at $0 \mathrm{~min}, 10 \mathrm{~min}$, $20 \mathrm{~min}, 30 \mathrm{~min}, 40 \mathrm{~min}, 60 \mathrm{~min}$, and $90 \mathrm{~min}$.

The preheated zihua snap bean lectin could be completely digested by pepsin in SGF in $10 \mathrm{~min}$ (Figure 11a). Similarly, no obvious lectin bands were observed in SIF after $10 \mathrm{~min}$ (Figure 11b). It meant that the digestibility of lectin from the Zihua snap bean was changed to some extent by thermal treatment. Some studies proved that the partial structure of lectin after preheating treatment was unfolded, which was helpful to improve the in vitro enzymatic hydrolysis of lectins [16].

\subsection{Antimicrobial of Zihua Snap Bean Lectin}

\subsubsection{Antibacterial Activity of Zihua Snap Bean Lectin}

The inhibition of S. aureus, E. coli, and B. subtilis by the Zihua snap bean lectin is shown in Figure 12a-c, respectively. Figure $12 \mathrm{~d}-\mathrm{f}$ were the positive control of phenol. The in vitro antibacterial experiment indicated that the Zihua snap bean lectin showed antibacterial activity against the tested bacteria (S. aureus, E. coli, and B. subtilis). Lectins have the ability to recognize carbohydrates (e.g., peptidoglycan and lipopolysaccharide) on the surface of bacterial cells [48]. The antibacterial activity of lectins was attributed to their interaction with the glycans of the bacterial cell wall [49]. In addition, antibacterial lectins can promote protein leakage and the formation of pores in the cell wall [50]. As shown in Figure 12, S. 
aureus, E. coli, and B. subtilis were capable of being inhibited by the lectin. At the same concentration, the antibacterial effect of lectin was stronger than that of phenol. The corresponding diameter of inhibition halos was shown in Table 6. As the lectin addition amount increased, the inhibition halo grew larger. Romero et al. [30] indicated that Phthirusa pyrifolia leaf lectin (PpyLL) had an inhibitory effect on B. subtilis, but not on $S$. aureus, when the addition amount was $80 \mu \mathrm{g}$. Lectin from the seeds of Archidendron jiringa Nielsen was detected to have inhibition for B. subtilis and S. aureus, whereas it did not for E. coli [51]. Some studies have shown that the lectin had a greater inhibition on Gram-positive bacteria than Gram-negative bacteria [30,51]. Our results agreed with this observation. The difference of the peptidoglycan content of cell walls of Gram-positive bacteria and Gram-negative bacteria was the main cause of this condition.

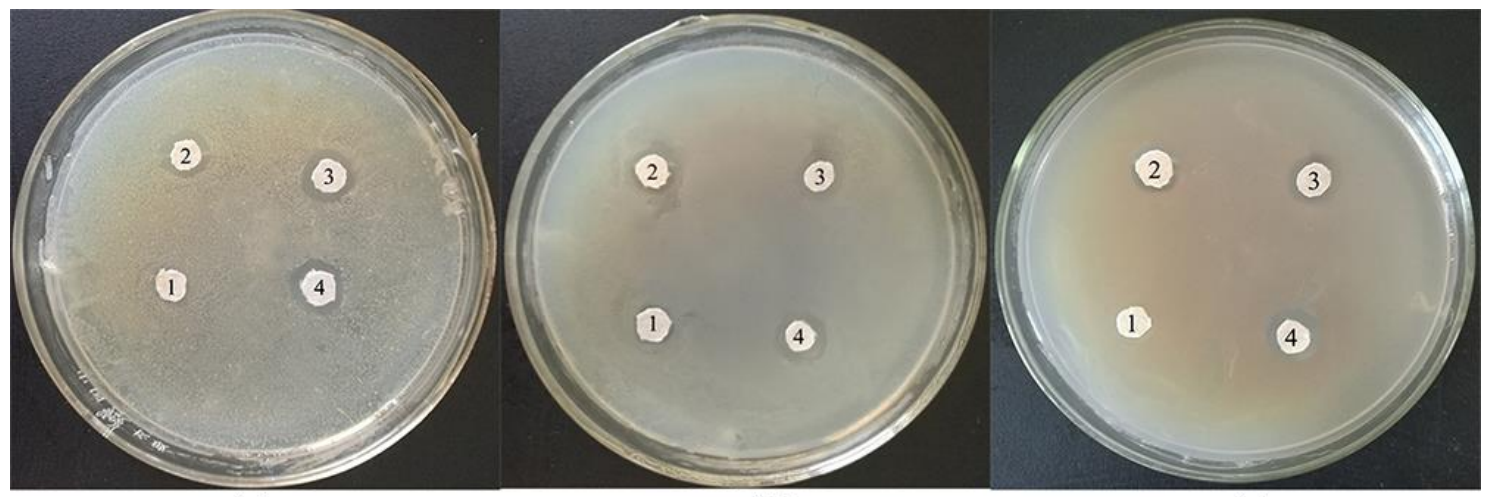

(a)

(b)

(c)

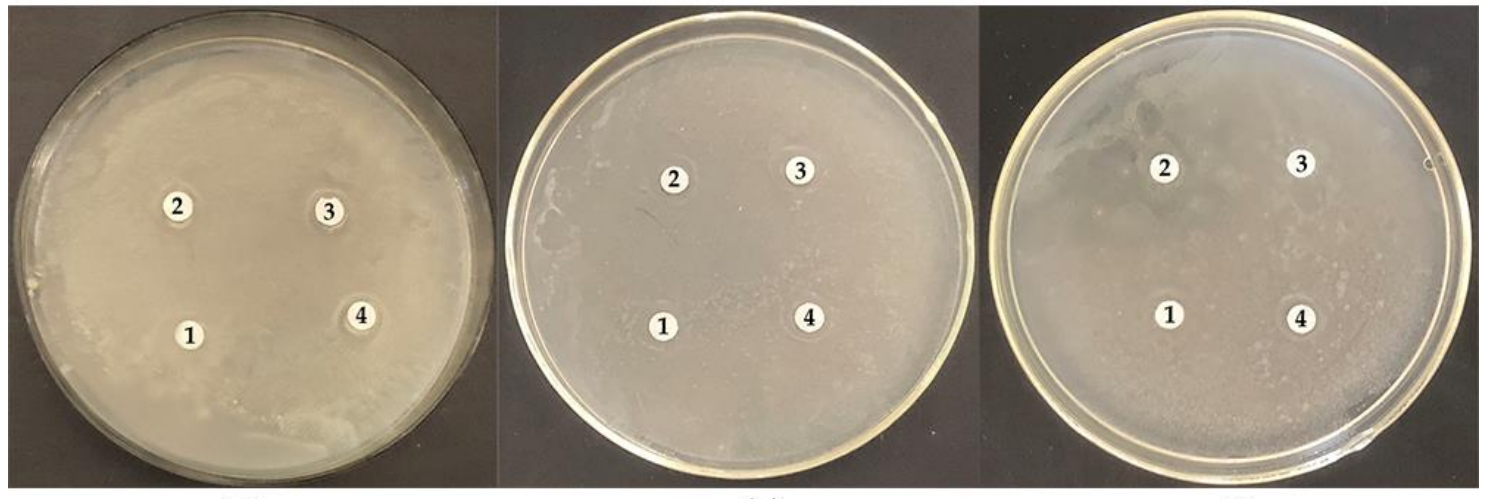

(d)

(e)

(f)

Figure 12. Inhibition of (a) S. aureus, (b) E. coli, and (c) B. subtilis with different concentrations (1, stroke-physiological saline solution; $2,10 \mu \mathrm{g} ; 3,20 \mu \mathrm{g} ; 4,50 \mu \mathrm{g}$ ) of lectin. Inhibition of (d) S. aureus, (e) E. coli, and (f) B. subtilis with different concentrations (1, stroke-physiological saline solution; 2, $10 \mu \mathrm{g} ; 3,20 \mu \mathrm{g} ; 4,50 \mu \mathrm{g}$ ) of phenol.

Table 6. The bacteriostatic circle diameter of bacteria with different concentrations of lectin.

\begin{tabular}{ccc}
\hline Bacterial & Different Addition Amount $(\boldsymbol{\mu g})$ & Inhibition Halo $(\mathbf{m m})$ \\
\hline \multirow{3}{*}{ S. aureus $\left(\mathrm{G}^{+}\right)$} & 10 & $10.5 \pm 0.5$ \\
& 20 & $12.1 \pm 0.8$ \\
& 50 & $14.5 \pm 1.1$ \\
\hline \multirow{2}{*}{ E. coli $\left(\mathrm{G}^{-}\right)$} & 10 & $8.2 \pm 0.8$ \\
& 20 & $10.1 \pm 0.8$ \\
& 50 & $11.6 \pm 0.5$ \\
B. subtilis $\left(\mathrm{G}^{+}\right)$ & 10 & $8.8 \pm 1.0$ \\
& 20 & $10.70 \pm 0.5$ \\
& 50 & $12.7 \pm 0.7$ \\
\hline
\end{tabular}




\subsubsection{Antifungal Activity of Zihua Snap Bean Lectin}

As indicated in Figure 13, the Zihua snap bean lectin showed an inhibitory effect on P. infestans when the addition amount was $100 \mu \mathrm{g}$ ( $20 \mu \mathrm{L}$ of $5 \mathrm{mg} / \mathrm{mL}$ lectin solution). Compared with the results of antibacterial experiments, the Zihua snap bean lectin can inhibit the growth of $P$. infestans at a high concentration. According to de Santana [35], only a few lectins had significant antifungal activity. In addition, lectins from kidney beans have inhibitory effects on four harmful fungi (Helminthosporium maydis, Sclerotinia sclerotiorum, Gibberalla sanbinetti, and Rhizoctonia solani) in agriculture [52]. Lectins interacting with chitin, $\alpha$-mannan, and $\beta$-glucan in the cell walls can lead to growth inhibition, cell wall disruption, reduced absorption of nutrients, and interference with spore germination, which is the main reason for the antifungal activity of lectins [53].

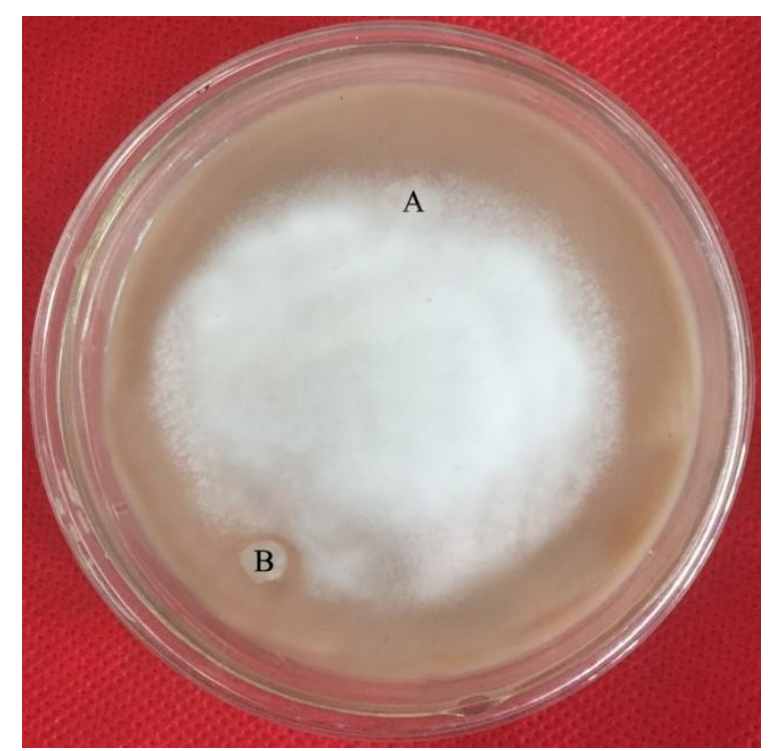

Figure 13. Inhibition of the P. infestans with lectin (B) and stroke-physiological saline solution (A).

\section{Conclusions}

The properties of the lectin isolated and purified by the two-step method were studied in this study. Through the experimental study on the affinity characteristics of lectin, it found that glucose, $\mathrm{N}$-acetyl-D-glucosamine, D-galactose, $\mathrm{N}$-acetyl-D-galactosamine, fructose, sucrose, D-maltose, D-trehalose, and lactose could not inhibit the hemagglutinating activity of the lectin and $\mathrm{Mn}^{2+}, \mathrm{Ca}^{2+}$, and $\mathrm{Mg}^{2+}$ ions can restore the hemagglutinating activity of the lectin. The results of the thermal stability indicate that the hemagglutinating activity of the lectin is changed with the change of protein conformation. Studies on the $\mathrm{pH}$ stability of the lectin show that the lectin maintains its hemagglutinating activity in the range of $\mathrm{pH} 2.0$ to 10.0. The SDS-PAGE of the in vitro digestion found that the native lectin is almost completely digested by pepsin at $60 \mathrm{~min}$ in SGF, while a distinct lectin band is observed in SIF for $90 \mathrm{~min}$. However, the lectin pretreated is completely digested by pepsin or trypsin in about $10 \mathrm{~min}$. Antibacterial assays demonstrate that the lectin exhibits antibacterial activity against $S$. aureus, E. coli, and B. subtilis. In addition, the lectin shows inhibition on the growth of phytophthora infestans at a high concentration.

Author Contributions: Data curation, X.W., L.W. and X.L.; Funding acquisition, B.J.; Investigation, D.L.; Methodology, B.J., C.L. and Z.F.; Project administration, B.J. and Z.F.; Writing—original draft, X.W.; Writing一review \& editing, B.J. and Z.F.

Funding: This research was funded by the National Natural Science Foundation of China (No. 31201366), the Natural Science Foundation of Heilongjiang Province (C2018019), the Research Science Foundation in Technology Innovation of Harbin (2016RAQXJ052), and the Northeast Agricultural University Students' Innovation and Entrepreneurship Training Program (2019). 
Conflicts of Interest: The authors declare no conflict of interest.

\section{References}

1. Rubeena, A.S.; Divya, M.; Vaseeharan, B.; Karthikeyan, S.; Ringo, E.; Preetham, E. Antimicrobial and biochemical characterization of a C-type lectin isolated from pearl spot (Etroplus suratensis). Fish Shellfish Immunol. 2019, 87, 202-211. [CrossRef]

2. Silva, M.C.C.; Santana, L.A.; Mentele, R.; Ferreira, R.S.; de Miranda, A.; Silva-Lucca, R.A.; Sampaio, M.U.; Correia, M.T.S.; Oliva, M.L.V. Purification, primary structure and potential functions of a novel lectin from Bauhinia forficata seeds. Process Biochem. 2012, 47, 1049-1059. [CrossRef]

3. Lagarda-Diaz, I.; Guzman-Partida, A.M.; Urbano-Hernandez, G.; Ortega-Nieblas, M.M.; Robles-Burgueño, M.R.; Winzerling, J.; Vazquez-Moreno, L. Insecticidal Action of PF2 Lectin from Olneya tesota (Palo Fierro) against Zabrotes subfasciatus Larvae and Midgut Glycoconjugate Binding. J. Agric. Food Chem. 2009, 57, $689-694$. [CrossRef]

4. Li, J.; Qu, X.; Payne, G.F.; Zhang, C.; Zhang, Y.; Li, J.; Ren, J.; Hong, H.; Liu, C. Biospecific Self-Assembly of a Nanoparticle Coating for Targeted and Stimuli-Responsive Drug Delivery. Adv. Funct. Mater. 2015, 25, 1404-1417. [CrossRef]

5. da Silva, J.S.; Oliveira, M.D.; de Melo, C.P.; Andrade, C.A. Impedimetric sensor of bacterial toxins based on mixed (Concanavalin A)/polyaniline films. Colloids Surf B Biointerfaces 2014, 117, 549-554. [CrossRef]

6. Macedo, M.L.; das Graças Machado Freire, M.; da Silva, M.B.; Coelho, L.C. Insecticidal action of Bauhinia monandra leaf lectin (BmoLL) against Anagasta kuehniella (Lepidoptera: Pyralidae), Zabrotes subfasciatus and Callosobruchus maculatus (Coleoptera: Bruchidae). Comp. Biochem. Physiol. 2007, 146, 486-498. [CrossRef]

7. Lagarda-Diaz, I.; Guzman-Partida, A.M.; Vazquez-Moreno, L. Legume Lectins: Proteins with Diverse Applications. Int. J. Mol. Sci. 2017, 18, 1242. [CrossRef] [PubMed]

8. Mello Ede, O.; dos Santos, I.S.; Carvalho Ade, O.; de Souza, L.S.; de Souza-Filho, G.A.; do Nascimento, V.V.; Machado, O.L.; Zottich, U.; Gomes, V.M. Functional expression and activity of the recombinant antifungal defensin PvD1r from Phaseolus vulgaris L. (common bean) seeds. BMC Biochem. 2014, 15, 1-13. [CrossRef] [PubMed]

9. Lusvarghi, S.; Bewley, C.A. Griffithsin: An Antiviral Lectin with Outstanding Therapeutic Potential. Viruses 2016, 8, 296. [CrossRef]

10. Shen, L.; Luo, Z.; Wu, J.; Qiu, L.; Luo, M.; Ke, Q.; Dong, X. Enhanced expression of alpha2,3-linked sialic acids promotes gastric cancer cell metastasis and correlates with poor prognosis. Int. J. Oncol. 2017, 50, 1201-1210. [CrossRef] [PubMed]

11. Blomme, B.; Van Steenkiste, C.; Callewaert, N.; Van Vlierberghe, H. Alteration of protein glycosylation in liver diseases. J. Hepatol. 2009, 50, 592-603. [CrossRef]

12. Fekete, F.; Fadgyas, B.; Papp, E.; Szilagyi, A.; Prohaszka, Z.; Muller, B.; Kovacs, G. The role of mannose binding lectin on fever episodes in pediatric oncology patients. Pathol. Oncol. Res. 2016, 22, 139-143. [CrossRef]

13. Nunes, B.S.; Rensonnet, N.S.; Dal-Secco, D.; Vieira, S.M.; Cavada, B.S.; Teixeira, E.H.; Moura, T.R.; Teixeira, C.S.; Clemente-Napimoga, J.T.; Cunha, F.Q.; et al. Lectin extracted from Canavalia grandiflora seeds presents potential anti-inflammatory and analgesic effects. Naunyn Schmiedebergs Arch. Pharmacol. 2009, 379, 609-616. [CrossRef] [PubMed]

14. Nareddy, P.K.; Bobbili, K.B.; Swamy, M.J. Purification, physico-chemical characterization and thermodynamics of chitooligosaccharide binding to cucumber (Cucumis sativus) phloem lectin. Int. J. Biol. Macromol. 2017, 95, 910-919. [CrossRef] [PubMed]

15. Zhang, J.S.; Shi, J.; Ilic, S.; Jun Xue, S.; Kakuda, Y. Biological Properties and Characterization of Lectin from Red Kidney Bean (Phaseolus Vulgaris). Food Rev. Int. 2008, 25, 12-27. [CrossRef]

16. He, S.D.; Shi, J.; Walid, E.; Zhang, H.; Ma, Y.; Xue, S.J. Reverse micellar extraction of lectin from black turtle bean (Phaseolus vulgaris): Optimisation of extraction conditions by response surface methodology. Food Chem. 2015, 166, 93-100. [CrossRef] 
17. Jiang, B.; Na, J.X.; Wang, L.L.; Li, D.M.; Liu, C.H.; Feng, Z.B. Separation and Enrichment of Antioxidant Peptides from Whey Protein Isolate Hydrolysate by Aqueous Two-Phase Extraction and Aqueous Two-Phase Flotation. Foods 2019, 8, 34. [CrossRef]

18. Wang, N.; Lewis, M.J.; Brennan, J.G.; Westby, A. Effect of processing methods on nutrients and anti-nutritional factors in cowpea. Food Chem. 1997, 58, 59-68. [CrossRef]

19. Wickham, M.; Faulks, R.; Mills, C. In vitro digestion methods for assessing the effect of food structure on allergen breakdown. Mol. Nutr. Food Res. 2009, 53, 952-958. [CrossRef] [PubMed]

20. Astwood, J.D.; Leach, J.N.; Fuchs, R.L. Stability of food allergens to digesyion in vitro. Nat. Biotechnol. 1996, 14, 1269-1273. [CrossRef]

21. He, S.D.; Simpson, B.K.; Ngadi, M.O.; Ma, Y. In vitro studies of the digestibility of lectin from black turtle bean (Phaseolus vulgaris). Food Chem. 2015, 173, 397-404. [CrossRef]

22. Wong, J.H.; Ng, T.B. Purification of a trypsin-stable lectin with antiproliferative and HIV-1 reverse transcriptase inhibitory activity. Biochem. Biophys. Res. Commun. 2003, 301, 545-550. [CrossRef]

23. Xia, L.; Ng, T.B. A hemagglutinin with mitogenic activity from dark red kidney beans. J. Chromatogr. B Anal. Technol. Biomed. Life Sci. 2006, 844, 213-216. [CrossRef]

24. He, S.; Shi, J.; Walid, E.; Ma, Y.; Xue, S.J. Extraction and purification of a lectin from small black kidney bean (Phaseolus vulgaris) using a reversed micellar system. Process Biochem. 2013, 48, 746-752. [CrossRef]

25. Jiang, B.; Yuan, Y.; Zhang, X.; Feng, Z.B.; Liu, C.H. Separation and Enrichment of Lectin from Zihua Snap-Bean (Phaseolus vulgaris) Seeds by PEG 600-Ammonium Sulfate Aqueous Two-Phase System. Molecules 2017, 22, 1596. [CrossRef] [PubMed]

26. Jiang, B.; Na, J.X.; Wang, L.L.; Li, D.M.; Liu, C.H.; Feng, Z.B. Eco-Innovation in Reusing Food By-Products: Separation of Ovalbumin from Salted Egg White Using Aqueous Two-Phase System of PEG 1000/( $\left.\mathrm{NH}_{4}\right)_{2} \mathrm{SO}_{4}$. Polymers (Basel) 2019, 11, 238. [CrossRef]

27. Lee, S.Y.; Khoiroh, I.; Ling, T.C.; Show, P.L. Aqueous Two-Phase Flotation for the Recovery of Biomolecules. Sep. Purif. Rev. 2015, 45, 81-92. [CrossRef]

28. Iqbal, M.; Tao, Y.; Xie, S.; Zhu, Y.; Chen, D.; Wang, X.; Huang, L.; Peng, D.; Sattar, A.; Shabbir, M.A.; et al. Aqueous two-phase system (ATPS): An overview and advances in its applications. Biol. Proc. Online 2016, 18, 18. [CrossRef] [PubMed]

29. He, S.D.; Shi, J.; Ma, Y.; Xue, S.J.; Zhang, H.W.; Zhao, S.X. Kinetics for the thermal stability of lectin from black turtle bean. J. Food Eng. 2014, 142, 132-137. [CrossRef]

30. Costa, R.M.P.B.; Vaz, A.F.M.; Oliva, M.L.V.; Coelho, L.C.B.B.; Correia, M.T.S.; Carneiro-da-Cunha, M.G. A new mistletoe Phthirusa pyrifolia leaf lectin with antimicrobial properties. Process Biochem. 2010, 45, 526-533. [CrossRef]

31. Nascimento, C.O.; Costa, R.M.P.B.; Araújo, R.M.S.; Chaves, M.E.C.; Coelho, L.C.B.B.; Paiva, P.M.G.; Teixeira, J.A.; Correia, M.T.S.; Carneiro-da-Cunha, M.G. Optimized extraction of a lectin from Crataeva tapia bark using AOT in isooctane reversed micelles. Process Biochem. 2008, 43, 779-782. [CrossRef]

32. Suzuki, T.; Abe, T.; Umehara, K.; Choi, J.H.; Hirai, H.; Dohra, H.; Kawagishi, H. Purification and characterization of a lectin from the mushroom Hypsizigus marmoreus. Mycoscience 2015, 56, 359-363. [CrossRef]

33. Nagae, M.; Soga, K.; Morita-Matsumoto, K.; Hanashima, S.; Ikeda, A.; Yamamoto, K.; Yamaguchi, Y. Phytohemagglutinin from Phaseolus vulgaris (PHA-E) displays a novel glycan recognition mode using a common legume lectin fold. Glycobiology 2014, 24, 368-378. [CrossRef]

34. Brewer, C.F.; Brown, R.D.; Koenig, S.H. Metal ion binding and conformational transitions in concanavalin A: a structure-function study. J. Biomol. Struct. Dyn. 1983, 1, 961-997. [CrossRef] [PubMed]

35. de Santana, M.A.; Santos, A.M.; Oliveira, M.E.; de Oliveira, J.S.; Baba, E.H.; Santoro, M.M.; de Andrade, M.H. A novel and efficient and low-cost methodology for purification of Macrotyloma axillare (Leguminosae) seed lectin. Int. J. Biol. Macromol. 2008, 43, 352-358. [CrossRef]

36. Zhao, J.K.; Wang, H.X.; Ng, T.B. Purification and characterization of a novel lectin from the toxic wild mushroom Inocybe umbrinella. Toxicon 2009, 53, 360-366. [CrossRef]

37. Wang, Y.F.; Wu, B.Y.; Shao, J.J.; Jia, J.X.; Tian, Y.Q.; Shu, X.; Ren, X.J.; Guan, Y. Extraction, purification and physicochemical properties of a novel lectin from Laetiporus sulphureus mushroom. Lwt 2018, 91, 151-159. [CrossRef] 
38. Carbonaro, M.; Nucara, A. Secondary structure of food proteins by Fourier transform spectroscopy in the mid-infrared region. Amino Acids 2010, 38, 679-690. [CrossRef] [PubMed]

39. Shen, L.; Tang, C.H. Microfluidization as a potential technique to modify surface properties of soy protein isolate. Food Res. Int. 2012, 48, 108-118. [CrossRef]

40. Kavitha, M.; Bobbili, K.B.; Swamy, M.J. Differential scanning calorimetric and spectroscopic studies on the unfolding of Momordica charantia lectin. Similar modes of thermal and chemical denaturation. Biochimie 2010, 92, 58-64. [CrossRef]

41. Biswas, S.; Kayastha, A.M. Unfolding and refolding of leucoagglutinin (PHA-L), an oligomeric lectin from kidney beans (Phaseolus vulgaris). Biochim. Biophys. Acta 2004, 1674, 40-49. [CrossRef] [PubMed]

42. Maurice, R.E.; Roxana, I. Thermodynamics of protein unfolding: questions pertinent to testing the validity of the two-state model. Biophys. Chem. 1997, 64, 175-197.

43. Khan, F.; Ahmad, A.; Khan, M.I. Chemical, thermal and $\mathrm{pH}$-induced equilibrium unfolding studies of Fusarium solani lectin. IUBMB Life 2007, 59, 34-43. [CrossRef]

44. Jana, S.; Chaudhuri, T.K.; Deb, J.K. Effects of guanidine hydrochloride on the conformation and enzyme activity of streptomycin adenylyltransferase monitored by circular dichroism and fluorescence spectroscopy. Biochemistry (Moscow) 2006, 71, 1230-1237. [CrossRef]

45. Silvestrini, V.C.; GonÇAlves, D.B.; Granjeiro, P.A. Anti-nutritional factors and digestibility of protein in Cayocar brasiliense seeds. Food Sci. Technol. 2017, 37, 632-639. [CrossRef]

46. Grozdanovic, M.M.; Ostojic, S.; Aleksic, I.; Andjelkovic, U.; Petersen, A.; Gavrovic, J.M. Active actinidin retains function upon gastro-intestinal digestion and is more thermostable than the E-64-inhibited counterpart. J. Sci. Food Agric. 2014, 94, 3046-3052. [CrossRef]

47. Diana, M.; Tatiana, S.; Vitalie, I.R. Calcium Ions Make Phytohemagglutinin Resistant to Trypsin Proteolysis. J. Agric. Food Chem. 2008, 56, 3764-3771.

48. Santi-Gadelha, T.; de Almeida Gadelha, C.A.; Aragao, K.S.; de Oliveira, C.C.; Lima Mota, M.R.; Gomes, R.C.; de Freitas Pires, A.; Toyama, M.H.; de Oliveira Toyama, D.; de Alencar, N.M.; et al. Purification and biological effects of Araucaria angustifolia (Araucariaceae) seed lectin. Biochem. Biophys. Res. Commun. 2006, 350, 1050-1055. [CrossRef]

49. Sunanta, R.; Wayakorn, N.; Montri, C. Interaction of a mulberry leaf lectin with a phytopathogenic bacterium, P. syringae pv mori. Plant Sci. 2001, 160, 739-744.

50. da Silva, J.D.F.; da Silva, S.P.; da Silva, P.M.; Vieira, A.M.; de Araujo, L.C.C.; de Albuquerque Lima, T.; de Oliveira, A.P.S.; do Nascimento Carvalho, L.V.; da Rocha Pitta, M.G.; de Melo Rego, M.J.B.; et al. Portulaca elatior root contains a trehalose-binding lectin with antibacterial and antifungal activities. Int. J. Biol. Macromol. 2019, 126, 291-297. [CrossRef]

51. Charungchitrak, S.; Petsom, A.; Sangvanich, P.; Karnchanatat, A. Antifungal and antibacterial activities of lectin from the seeds of Archidendron jiringa Nielsen. Food Chem. 2011, 126, 1025-1032. [CrossRef]

52. Chen, J.; Liu, B.; Ji, N.; Zhou, J.; Bian, H.J.; Li, C.Y.; Chen, F.; Bao, J.K. A novel sialic acid-specific lectin from Phaseolus coccineus seeds with potent antineoplastic and antifungal activities. Phytomedicine 2009, 16, 352-360. [CrossRef] [PubMed]

53. da Silva, P.M.; de Moura, M.C.; Gomes, F.S.; da Silva Trentin, D.; Silva de Oliveira, A.P.; de Mello, G.S.V.; da Rocha Pitta, M.G.; de Melo Rego, M.J.B.; Coelho, L.; Macedo, A.J.; et al. PgTeL, the lectin found in Punica granatum juice, is an antifungal agent against Candida albicans and Candida krusei. Int. J. Biol. Macromol. 2018, 108, 391-400. [CrossRef] [PubMed]

(C) 2019 by the authors. Licensee MDPI, Basel, Switzerland. This article is an open access article distributed under the terms and conditions of the Creative Commons Attribution (CC BY) license (http://creativecommons.org/licenses/by/4.0/). 